MARZENA LIEDKE

Instytut Historii i Nauk Politycznych Uniwersytetu w Białymstoku

PIOTR GUZOWSKI

Instytut Historii i Nauk Politycznych Uniwersytetu w Białymstoku

Instytut Historii Polskiej Akademii Nauk

\title{
PROBLEMY FINANSOWE EWANGELICKIEJ JEDNOTY LITEWSKIEJ W PIERWSZEJ POEOWIE XVII W. W ŚWIETLE AKT SYNODÓW PROWINCJONALNYCH*
}

Zarys treści: Celem artykułu jest przedstawienie systemu zarządzania finansami oraz wykazanie faktycznego położenia ekonomicznego Kościoła ewangelicko-reformowanego w Wielkim Księstwie Litewskim w pierwszej połowie XVII w. w związku z funkcjonującymi w dotychczasowej literaturze przedmiotu opiniami o zadowalającej sytuacji finansowej Jednoty w tym okresie. Autorzy zamierzają wskazać czynniki, które wpływały na sytuację ekonomiczna tego Kościoła w okresie zintensyfikowania akcji kontrreformacyjnej ze strony Kościoła katolickiego i omówić przejawy jego niewątpliwego kryzysu ekonomicznego. Wśród nich szczególną uwagę zwrócono na niesolidność urzędników finansowych Jednoty, kłopoty z zarządzaniem pożyczkami oraz problemy z odzyskiwaniem i realizacją darowizn na rzecz Kościoła. Podstawę źródłowa artykułu stanowia protokoły synodów prowincjonalnych Jednoty Litewskiej z lat 1611-1655, w znacznej części poświęcone sprawom ekonomicznym.

The content outline: The purpose of the article is to present a financial management system of the Evangelical Reformed Church and the Church situation in the Grand Duchy of Lithuania in the first half of the seventeenth century, in order to verify the opinions about the satisfactory financial situation of the Unity (Polish: Jednota) in that period that could be found in the literature on the subject. The authors indicate all factors influencing the economic position of the Unity in the period of intensified counter-Reformation actions of the Roman Catholic Church, and discuss symptoms of its undoubted economic crisis. Among these special attention is paid to unreliability of the Unity's

\footnotetext{
* Artykuł został opracowany w ramach realizacji projektu badawczego Narodowego Centrum Nauki (nr 2012/05/B/HS3/03844).
} 
financial officers, troubles with the management of loans and problems with getting back and receiving donations made to the Unity. The article is based on records of provincial synods of the Lithuanian Unity in the period of 1611-1655 , in their large part devoted to financial matters.

Słowa kluczowe: Jednota Litewska, kryzys finansowy, zbór wileński, pożyczki

Keywords: Lithuanian Unity, financial crisis, Vilnius Protestant Church, loans

Jest oczywiste, że żadna wspólnota finansowa nie może funkcjonować bez podstaw materialnych warunkujacych jej skuteczne działanie oraz rozwój. W Rzeczypospolitej Obojga Narodów statusem kościoła panującego, wspieranego przez władcę, cieszył się Kościół rzymskokatolicki, jednak patronat magnacki, szlachty czy bogatego mieszczaństwa umożliwiał istnienie i rozwój nie tylko katolicyzmu, ale także m.in. kalwinizmu, antytrynitaryzmu, luteranizmu czy prawosławia. Kiedy wraz z rozwojem kontrreformacji nasiliły się konwersje dotychczasowych wyznawców, a Kościół katolicki rozpoczął akcję rewindykacyjną świątyń zamienionych wcześniej na zbory, sytuacja materialna ewangelików reformowanych także zaczęła ulegać pogorszeniu. W związku z tym, jak zauważył Marceli Kosman: „Protestanci polscy w drugiej połowie XVII wieku oczekiwali pomocy materialnej od współwyznawców z zagranicy. Była ona jednak niezbędna przede wszystkim w Koronie, Litwini - choć ponieśli znaczne uszczerbki - znajdowali się w lepszej sytuacji”. Z kolei Stanisław Kot, pisząc o poszukiwaniu przez ewangelików wsparcia materialnego w Anglii, oceniał: „Podejmując ten krok Kościół litewski [ewangelicko-reformowany - ML, PG] nie czuł się w roli żebraka, ale apelował do współwyznawców zagranicznych o pomoc, której w czasach swego dobrobytu hojnie udzielał protestantom innych narodów"2.

Obaj autorzy nie oceniali źle sytuacji ekonomicznej Jednoty Litewskiej w pierwszej połowie XVII w., wskazując na pewien kryzys raczej $\mathrm{w}$ drugiej połowie tego stulecia. Mimo tych opinii w dotychczasowej literaturze zajmującej się rozwojem, a później regresem wspólnoty ewangelików reformowanych w Wielkim Księstwie Litewskim kwestie finansowe nie znalazły jednak rozwinięcia. Zwykle podkreślano kluczowe znaczenie patronatu średniej i bogatej szlachty oraz mecenatu magnac-

${ }^{1}$ M. Kosman, Litewska jednota ewangelicko-reformowana od połowy XVII $w$. do 1939 r., Opole 1986, s. 46.

2 S. Kot, Geneza i tło historyczne Biblii Litewskiej Chylińskiego, w: Biblia Litewska Chylińskiego. Nowy Testament, t. 2: Tekst, Poznań 1958, s. XIX. 
kiego Radziwiłłów, które miały zapewniać solidne podstawy materialne funkcjonowania wspólnoty ewangelicko-reformowanej w Wielkim Księstwie Litewskim ${ }^{3}$. W tym duchu powstawały też monograficzne opracowania dziejów poszczególnych zborów ${ }^{4}$. Tymczasem lektura protokołów corocznych synodów prowincjonalnych Jednoty Litewskiej pokazuje, że problemy ekonomiczne zajmowały elitę ewangelicką nie mniej niż kwestie teologiczne, doktrynalne czy dyscyplinarne (zob. wykres 1). Blisko połowa uchwalanych przez synod kanonów dotyczyła kwestii finansowo-gospodarczych, a w 1642 r. stwierdzono wręcz: „Iż rachunki są anima wszytkich spraw na Synodzie się wentylujaccych" ${ }^{5}$. Dlatego potrzebna wydaje się prezentacja rzeczywistej sytuacji ekonomicznej Jednoty Litewskiej w pierwszej połowie XVII w., w celu zbadania, czy funkcjonowała ona względnie bezproblemowo, jak sugerowali to cytowani wyżej autorzy, czy przeciwnie - doświadczała jednak kłopotów finansowych. W naszej próbie wykorzystamy przede wszystkim protokoły akt synodów prowincjonalnych Kościoła ewangelicko-reformowanego w Wielkim Księstwie Litewskim, zachowane od 1611 r. i częściowo dla okresu 1611-1655 wydane już drukiem ${ }^{6}$. Śledzenie interesujacej nas

${ }^{3}$ U. Augustyniak, Duchowni klienci Krzysztofa II Radziwitła. Kondycja i funkcje duchowienstwa ewangelicko-reformowanego $w$ dobrach radziwitłowskich $w$ pierwszej połowie XVII wieku, w: Radziwiłtowie XVI-XVIII w. W kręgu polityki i kultury, Warszawa-Łódź 1989 (Miscelanea Historico-Archivistica, 3), s. 159-173; taż, „Druga reformacja” $w$ Wielkim Księstwie Litewskim w pierwszej połowie XVII wieku. W poszukiwaniu tożsamości wyznaniowej, w: Sztuka i dialog wyznań w XVI i XVII wieku. Materiaty Sesji Historyków Sztuki, Wrocław, listopad 1999, red. J. Harasimowicz, Wrocław 2000, s. 223-233.

${ }^{4}$ E. Bagińska, Działalność religijna Radziwitłów birżańskich $w$ dobrach podlaskich w XVII wieku, „Studia Podlaskie” 12, 2002, s. 205-228; J. Maroszek, Dzieje zboru kalwińskiego w Zabłudowie w latach 1608-1868, „Rocznik Zabłudowski” 3, 2009, s. 5-55; M. Sierba, Kalwiński zbór orlański w XVII wieku, „Białoruskie Zeszyty Historyczne" 44, 2015, s. 45-61.

${ }^{5}$ Biblioteka im. E. i E. Wróblewskich Litewskiej Akademii Nauk w Wilnie (dalej: BLAN), f. 40, sygn. 1136, kanon 6 (O rachunkach) z 1642 r.

${ }^{6}$ Akta synodów prowincjalnych Jednoty Litewskiej 1611-1625, Wilno 1915 (Monumenta Reformationis Polonicae et Lithuanicae, IV, 2) (dalej: Akta synodów prowincjalnych... 1611-1625); Akta synodów prowincjonalnych Jednoty Litewskiej 1626-1637, wstęp i oprac. M. Liedke, P. Guzowski, Warszawa 2011 (dalej: Akta synodów prowincjonalnych... 1626-1637); protokoły z lat 1638-1655 zostały opracowane edytorsko i oddane do druku, ale posługiwać się będziemy odniesieniami do sygnatury rękopisu przechowywanego w oddziale rękopisów BLAN, f. 40, sygn. 1136, k. 1b-212. Dlatego w przypisach podajemy numer kanonu, a nie stronę $\mathrm{z}$ rękopisu; ponadto $\mathrm{w}$ ten sposób łatwiej można sprawdzić treść danego kanonu w znajdujących się w Warszawie odpisach, z których najczęściej korzystają badacze polscy (np. AGAD, Archiwum Radziwiłłów, dz. VIII, sygn. 713). 
Wykres 1. Liczba kanonów poświęconych sprawom ekonomicznym w aktach synodów prowincjonalnych Jednoty Litewskiej w latach 1611-1655

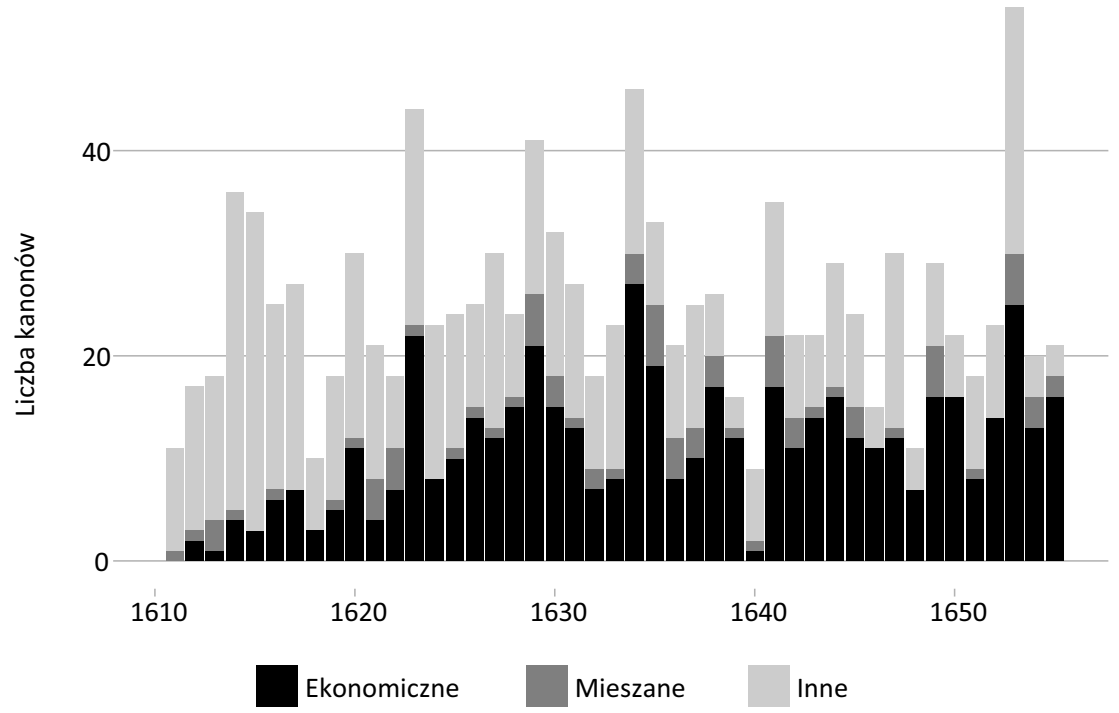

Źródło: oprac. własne na podstawie: BLAN, f. 40, sygn. 1136.

kwestii w oparciu o te źródła uzasadnia fakt, że oprócz ujęcia ogólnego poszczególnych kwestii protokoły te zajmowały się sprawami poszczególnych, konkretnych zborów.

Artykuł nie pretenduje do całościowego ujęcia zagadnienia, zasługującego bez wattpienia na odrębne - monograficzne - ujęcie, ale skupia się na omówieniu niektórych zauważonych problemów finansowych Jednoty. Zanim przejdziemy do prezentacji poszczególnych kwestii, przedstawimy organizację kontroli nad finansami wspólnoty ewangelickiej: główne urzędy bezpośrednio odpowiedzialne za zawiadywanie środkami finansowymi, dokumentacje prowadzona przez osoby je pełniące oraz źródła dochodów Jednoty.

\section{Organizacja zarządzania sprawami ekonomicznymi Jednoty}

Z lektury akt synodalnych wynika, że można wskazać dwie główne funkcje - aktora zborowego (pełnomocnika prawnego) i szafarzy oraz doraźnie powoływane gremia (komisje) zwiazane z zarządzaniem i odpowiedzialnością finansową ewangelicko-reformowanej wspólnoty wyznaniowej. 
Osobą odpowiedzialna za organizację i funkcjonowanie w życiu codziennym wspólnoty ewangelickiej był tzw. aktor, zwany wileńskim, zborowym lub „aktorem zborów naszych”. Była to osoba świecka, ze stanu szlacheckiego, wybierana przez synod, z którą podpisywano specjalny kontrakt gwarantujący jej wynagrodzenie i przekazujący plenipotencję do działań prawnych ${ }^{8}$. Jak pisali pierwsi wydawcy akt synodowych: „od jego sprężystości i umiejętności zależną była windykacja zapisów, legatów i zobowiąań, tj. materialny dobrobyt Jednoty" ". Początkowo zadania aktora były w aktach synodowych i kontraktach opisywane bardzo ogólnie, ale przypisywały mu olbrzymi zakres obowiązków i władzy, z których miał się rozliczać przed synodem. W kontrakcie zawartym z Mikołajem Sosnowskim, wybranym na plenipotenta Jednoty w 1640 r., patroni zborów Wielkiego Księstwa Litewskiego przekazali mu szerokie uprawnienia: „Przetoż onemu wszystkie sprawy zborowe zleciwszy, daje mu moc i władzę zupełną wszytkie zborowe ewangelickie sprawy w któregokolwiek sądu wyższego i niższego, bądź ex nostro, bądź ex alieno aktoratu przypadające odprawować, zapisy, kontrakty imieniem zborowym stanowić i zawierać, albo z nich kwitować, i wszystko to co de iure et consuetudine. Przetoż z onym aktorem competit, wykonywać. A my wszystko pro rato et grato, lub by zysk, lub strata za tym szła, przyjąc powinni będziemy"10.

Szczegółowe zadania aktora najpełniej opisane sa w kanonie 1 z 1644 r. Do jego obowiązków należało przede wszystkim reprezentowanie Jednoty przed sądami oraz troska o jej kapitał: ,aby sumy kapitalne już effectualiter darowane żadna miarą na rozchody nie szły i najmniejsza w nich dyminucja nie była. Po wtóre prowentami od sum obligowanych majętności leżących kamienic, domów, placów, co rok idącymi szafować będzie podług osobliwej ordynacji od Synodu sobie danej, ekspensów zbytnich nie czyniąc. A nad to nic nie powinien dawać bez kwitu". Ponadto aktor zborów Wielkiego Księstwa Litewskiego mógł udzielać pożyczki z nadwyżki pozostałej po opłaceniu wydatków i wynagrodzenia osób pracujacych przy zborach, ,jeśliby kto dobrze osiadły i wiarygodny trafił”. Powinien także sporządzać inwentarz „,wszytkich sum jako wyderkaufowych, jako obligowych, osobliwie w osobliwe księgi porządnie spisanych”, składać corocznie na synodzie sprawozdania „z administracji swojej”, a w przypadku odejścia z urzędu spisać inwentarz:

${ }^{7}$ BLAN, f. 40, sygn. 1136, kanon 17 z 1642 r.

8 Przykładem jest zachowany kontrakt podpisany między Mikołajem Sosnowskim a patronami zborów w $1640 \mathrm{r}$.

${ }^{9}$ Akta synodów prowincjalnych... 1611-1625, s. XIII.

${ }^{10}$ BLAN, f. 40, sygn. 409, k. 34 (4 VII 1640 r.). 
„Wszystkich praw, funduszów, obligów, rejestrów i rachunków” i przekazać go następcy. Zabroniono przy tym aktorowi podpisywania kontraktów „jako o majętności leżące, tak i kamienice, domy, place” bez zgody synodu, a także wywożenia z Wilna (do swojego domu lub gdziekolwiek indziej) „skrzynki ze sprawami zborowymi”11. W przerwach między obradami synodu aktor był więc kluczowa postacią w strukturach Jednoty, której rola jest trudna do przecenienia. Według kanonu 17 z 1644 r. „sumy którekolwiek dotąd na czyje insze imię kontraktowane bywały, vigore tego Synodu to stanowiemy, aby ex nunc na imię P. aktora dane były w kontrakt komukolwiek"12.

Najstarsze zachowane akta synodowe (od 1611 r.) aktorem i dozorca dóbr zborowych tytułuja Pawła Progulbickiego ${ }^{13}$, aktywnego działacza kalwińskiego, m.in. sygnatariusza porozumienia między ewangelikami a prawosławnymi zawartego w Wilnie w 1599 r. ${ }^{14}$, którego kadencję przedłużano co roku. W 1616 r. przydano mu koadiutorów: Rafała Roszczyca, sędziego lidzkiego, i Mikołaja Topczewskiego, seniora świeckiego wileńskiego ${ }^{15}$. Po kilku latach synod zdecydował dodać Progulbickiemu do pomocy Józefa Pietkiewicza, także seniora wileńskiego ${ }^{16}$, ,a do spraw prawnych pozwolono temuż P. Aktorowi chować kosztem Zborowym młodzieńca do tego sposobnego" ${ }^{17}$. W 1625 r. stanowisko aktora synod powierzył, zapewne już dobrze przygotowanemu, Józefowi Pietkiewiczowi ${ }^{18}$, ale także i jemu przydzielono pomocników: w 1625 r. Aleksandra Kurmina $^{19}$, a później (1636), na rok, Jana Kochlewskiego, wojskiego brzeskiego, i Jana Golimonta (do spraw sądowych), późniejszego (od 1652 r.)

11 Tamże, sygn. 1136, kanon 4 z 1644 r.

12 Tamże, kanon 17 z 1644 r.

${ }^{13}$ Akta synodów prowincjalnych... 1611-1625, s. 5.

14 J.I. Kraszewski, Wilno od poczatków jego do roku 1750, t. 1, Wilno 1840, s. 411. Porozumienie to miało na celu doprowadzenie do zintensyfikowania politycznej współpracy protestantów i prawosławnych w celu obrony ich położenia jako innowierców, a także - w przyszłości - do ich religijnej jedności. Zjazd wileński „umocnił praktyczne współdziałanie różnowierców w sferze publicznej w obronie swobody wyznaniowej”; T. Kempa, Konflikty wyznaniowe w Wilnie od poczatku reformacji do końca XVII wieku, Toruń 2016, s. 240.

15 Akta synodów prowincjalnych... 1611-1625, s. 38.

${ }_{16}$ W indeksie osób akt synodalnych z lat 1611-1625 wspomniano, że było on pisarzem ziemskim wileńskim (tamże, s. 121), jednak wydawcy serii Urzędnicy Wielkiego Księstwa Litewskiego nie podają informacji o Pietkiewiczu tego imienia żyjącym w pierwszej połowie XVII w.

17 Tamże, 65.

18 Tamże, s. 92; od 1624 r. był koadiutorem Progulbickiego; tamże, s. 84.

19 Tamże, s. 92. 
aktora zborowego ${ }^{20}$. Według wskazówek synodu „wszystkie aktorskie powinności zgodnie i pilnie wykonywać będa, jeden bez drugiego nic nie czyniąc, owszem, się z sobą często znosząc, żeby przez ten rok jako najwięcej trudności zborowych ułacnić, sum pieniężnych odyskać i procentów przyczynić mogli”" ${ }^{21}$. W 1629 r. synod dodał aktorowi i koadiutorowi do pomocy „względem zawiadywania dobrami zborowymi” superintendenta wileńskiego wraz z dwoma ministrami (polskim i niemieckim), a także trzy osoby świeckie: Marcjana Górskiego, chorążego wileńskiego, Pawła Kleofasa Podchocimskiego ${ }^{22}$ i mieszczanina Korneliusa Winholda, „które osoby pomienione powinny się [...] na Trzy Króle do Wilna zjeżdżać i tam się ze sobą zniósłszy porachowanie uczynić" ${ }^{23}$. Dźwigając dużą odpowiedzialność przez wiele lat, Józef Pietkiewicz prosił o zwolnienie z funkcji aktora, ale nazywano go tym tytułem jeszcze w kolejnych latach (aż do 1641 r.). Nieformalnie w 1640 r. zadania aktora zlecono Mikołajowi Sosnowskiemu ${ }^{24}$, ale rok później oficjalnie wybrano na tę funkcję Jerzego Blinstruba, dworzanina królewskiego, z pensja $500 \mathrm{zł}^{25}$, i przydano mu koadiutora Jana Kamienieckiego z wynagrodzeniem $100 \mathrm{zł}^{26}$. Po roku Blinstrub został zastapiony przez Adama Rajeckiego, chorążego pernawskiego. Pełnomocnik Jednoty dostał swobodę wyboru koadiutora, któremu zaproponowano pensję 150 zł, choć zasugerowano jednocześnie, że może to być dotychczasowy pomocnik - Jan Kamieniecki ${ }^{27}$. Ze względu na „słabość zdrowia” Adam Rajecki zrezygnował z urzędu w 1645 r., a jego miejsce zajął Krzysztof Papłoński $^{28}$, którego już w 1649 r. synod uwolnił od tej funkcji, wybierajacc nowym aktorem Mikołaja Bykowskiego, podstolego trockiego ${ }^{29}$. Po trzech

${ }^{20}$ Akta synodów prowincjonalnych... 1626-1637, s. 150.

21 Tamże.

22 Paweł Kleofas Podchocimski z Brylewa był później budowniczym wileńskim (1633-1657) i horodniczym wileńskim (1634-1657); Urzędnicy Wielkiego Księstwa Litewskiego. Spisy, t. 1: Województwo wileńskie, XIV-XVIII wiek, oprac. H. Lulewicz, A. Rachuba, P.P. Romaniuk, współpr. U. Jemialianczuk, A. Macuk, Warszawa 2004, s. 100,709 .

${ }^{23}$ Tamże, s. 53.

${ }^{24}$ BLAN, f. 40, sygn. 1136, kanon 9 z 1641 r.; tamże, sygn. 409, kanon 34 (4 VII 1640 r.).

${ }^{25}$ Wszystkie sumy wymienione w tekście artykułu zostały podane za źródłem lub przeliczone przez autorów na złote polskie. Sumy pieniężne na kartach protokołów synodalnych podawano najczęściej w złotych polskich (również używając określenia „floren”), a także w kopach groszy litewskich.

${ }_{26}$ BLAN, f. 40, sygn. 1136, kanon 9 z 1641 r.

27 Tamże, kanon $10 \mathrm{z} 1642 \mathrm{r}$.

28 Tamże, kanon 24 z 1645 r.

29 Tamże, kanon 23 z 1649 r. 
latach decyzja synodu z 1652 r. został on zastapiony przez Jana Golimonta $^{30}$, wcześniejszego koadiutora Józefa Pietkiewicza.

W praktyce więc aktorzy kierowali organizacją kościelną w przerwach między corocznymi zebraniami synodu, które odbywały się w czerwcu lub lipcu. Dwaj najdłużej kierujący sprawami Jednoty aktorzy - Paweł Progulbicki i Józef Pietkiewicz - musieli się znakomicie sprawdzać w wyznaczonej im roli. Kolejni zaś, funkcjonujący w trudniejszych warunkach politycznych, nie zawsze stawali na wysokości zadania. Do zaszczytnej funkcji chętni się nie garnęli, czasem trzeba było „uprosić” kandydata ${ }^{31}$. Aktorzy musieli dbać o finanse Jednoty, ale też niejednokrotnie korzystali z obrotu pieniędzmi Kościoła ewangelicko-reformowanego. Jak wynika z akt synodowych Józef Pietkiewicz wprawdzie odzyskał 1 tys. zł pożyczonych przez zbór szylański na oblig pisarzowi wileńskiemu Aleksandrowi Sawgowiczowi, ale nie przekazał ich z powrotem Jednocie ${ }^{32}$. Po 15 latach pracy na rzecz wspólnoty był jej winien łącznie 4050 zł, które zapisał na majętności Glinkiszki (Glinciszki). Ewangelicy nie mieli złudzeń, że je odzyskają i dlatego „mając Zbór Pański wzgląd na wierne usługi i na trudy i szwanki zdrowia, które w urzędzie aktorskim JMP Józef Pietkiewicz podejmował" darował mu wszystkie zobowiązania ${ }^{33}$. Z kolei znacznie krócej, bo tylko rok (1641/1642), urzędujacy Jerzy Blinstrub zostawił aktorstwo dłużny Jednocie 423 zł i 10 gr $^{34}$, które zostały $\mathrm{mu}$ ostatecznie darowane $\mathrm{w} 1646 \mathrm{r} \cdot{ }^{35}$ Czasami funkcję pełnomocnika prawnego Jednoty sprawowały osoby niekompetentne, których „gospodarowanie" finansami Jednoty sprawiało jej wiele kłopotów. Szczególnie nieudolnym aktorem okazał się Mikołaj Bykowski, którego poczynaniom poświęcił synod w $1650 \mathrm{r}$. cały kanon 1 . Bykowski „w swoich powinnościach [...] mniej ostrożny [...] nie dokładając się PP. seniorów wileńskich dwa domy zborowe: jeden JMP Bielikowiczowi a drugi P. Wysockiemu zawiódł, a tak Zbór Boży gravaminibus i sumptibus onerował i do wielkiego periculu [m] ratione possessioni tego miejsca przywiódł" ${ }^{36}$.

Na poziomie poszczególnych zborów funkcje gospodarcze, zarządzania majątkiem zborowym, pełnili szafarze. Ich zadania sformułowano w aktach synodowych w 1629 r. następująco: „Powinność ich: zawiadywać kamienicami i domami zborowemi, pożytki z nich czynić Zborowi

\footnotetext{
30 Tamże, kanon 4 z 1652 r.

${ }^{31}$ Tamże, kanon 22 z 1649 r.

32 Tamże, kanon 3 z 1639 r.; tamże, kanon 18 z 1641 r.

33 Tamże, kanon 12 z 1644 r.

34 Tamże, kanon 10 z 1642 r.

35 Tamże, Memorialia, pkt 9 z 1646 r.

36 Tamże, kanon 1 z 1650 r.
} 
Pańskiemu, najmując je, a z tych pożytków szafować, gdzie potrzeba ukaże za zezwoleniem P. aktora i starszych" ${ }^{37}$. Akta synodów prowincjonalnych Jednoty wspominają zazwyczaj o szafarzach zboru wileńskiego ${ }^{38}$, od których wymagano, by „bez pozwolenia seniorów i ministrów na sesjej wileńskiej nikomu nie najmowali domów zborowych, aby tak zawsze mogła być wiadomość de vita mieszkających w domach" ${ }^{39}$. Oddzielnego szafarza miał też szpital przy zborze wileńskim ${ }^{40}$. Zapewne początkowo wybrana na stanowisko szafarza zborowego osoba pełniła funkcję przez roczną kadencję, z czasem kadencje przedłużano, a szafarzom wyznaczano pomocników (koadiutorów) do pomocy. Funkcje szafarzy pełnili zazwyczaj mieszczanie wileńscy, często obowiązki między siebie dzieliło w samym Wilnie kilka osób, które rozliczały się przed synodem ${ }^{41}$. Oddzielnie także wybierano szafarzy zboru polskiego i niemieckiego ${ }^{42}$.

Pierwsze zachowane protokoły synodowe z $1611 \mathrm{r}$. informuja, że funkcję szafarza pełnił mieszczanin wileński Łukasz Bossa ${ }^{43}$. W 1616 r. wybrano na nią także mieszczanina Michała Szerypę ${ }^{44}$. Później tę funkcję znowu pełnił Bossa, któremu w 1623 r. przydzielono koadiutora w osobie Marcina Gauttera ${ }^{45}$. Bossa nie sprawdził się jako szafarz, nie wywiazał się z obowiązków i narobił długów ${ }^{46}$, i od 1626 r. szafarzem wileńskim był samodzielnie wspomniany już Marcin Gautter Ubphagen ${ }^{47}$. W 1629 r. wybrano złotnika Jana Grekowicza i Mikołaja Aleksandrowicza, dotychczasowego szafarza szpitala wileńskiego (od 1624 r.), na szafarzy zboru polskiego, a także Jakuba de Saus ${ }^{48}$ i Piotra Kronę na szafarzy zboru niemieckiego ${ }^{49}$. W $1641 \mathrm{r}$. szafarzem był prawdopodobnie

${ }^{37}$ Akta synodów prowincjonalnych... 1626-1637, s. 63.

38 Tamże.

39 Tamże, s. 103.

40 Tamże, s. 118.

${ }^{41}$ BLAN, f. 40, sygn. 1136, kanon 5 z 1639 r.

${ }^{42}$ Akta synodów prowincjonalnych... 1626-1637, s. 52, 63.

${ }^{43}$ Akta synodów prowincjalnych... 1611-1625, s. 5.

44 Tamże, s. 39.

45 Tamże, s. 82.

46 Tamże, s. 101.

${ }^{47}$ Akta synodów prowincjonalnych... 1626-1637, s. 11.

48 Jakub de Saus (Desaus) był najprawdopodobniej mieszczaninem wileńskim (choć rodzina de Sausów pojawia się także w kontekście pochodzenia szlacheckiego) pochodzenia francuskiego, żonatym zapewne z siostra wspomnianego wyżej Korneliusza Winholda; zob. D. Frick, Libellius chamorum. Protestancka elita mieszczańska a szlachta w Wilnie XVII wieku, w: Litwa w epoce Wazów. Prace ofiarowane Henrykowi Wisnerowi $w$ siedemdziesiata rocznice urodzin, red. W. Kriegseisen, A. Rachuba, Warszawa 2006, s. 239-255.

${ }^{49}$ Akta synodów prowincjonalnych... 1626-1637, s. 52, 64. 
mieszczanin Marcin Niegowicz ${ }^{50}$, przed którym funkcję tę „przez kilka lat" sprawował także mieszczanin Matiasz Gierlicz ${ }^{51}$. Prawdopodobnie najpierw wspólnie z Niegowiczem, a później samodzielnie, szafarzem był również niejaki Żebrowski, być może Andrzej, szlachcic, niegdyśs szafarz szpitala wileńskiego, zwany szafarzem generalnym ${ }^{52}$. W 1652 r. z rachunków szafarskich rozliczył się Henryk Mones, późniejszy rajca i burmistrz wileński, również zwany szafarzem generalnym ${ }^{53}$. Pełnił on tę funkcję jeszcze w 1654 r., kiedy synod poprosił go o usługi na kolejny rok, dodając mu jako koadiutora Gizberta von Pitten ${ }^{54}$, świeckiego seniora wileńskiego. Synod 1655 r. przedłużył kadencję Monesa jako szafarza ${ }^{55}$.

Szafarze nie mogli cieszyć się pełnym zaufaniem - i niebezpodstawnie. Przykładem może być Łukasz Bossa ${ }^{56}$, którego synod za nierozliczenie się z powierzonych środków strofował kilkukrotnie w latach 20. i 30. Także i później synod surowo nakazał, by: „Szafarz zboru wileńskie[go] ani kamienicami, ani inszemi budynkami Zborowi Bożemu należącymi, bez konsensu wyraźnego Synodu S. szafować i dysponować nie ma"57.

Współpraca między aktorem a szafarzem lub szafarzami nie zawsze układała się dobrze, m.in. z powodu niekompetencji aktora. W 1650 r. synod stwierdził, „aby żadnych ekspensów P. aktor nie czynił, ale oddawając w ręce P. szafarzowi sumę, od niego kwity odbiera, dystrybucję onemu poleciwszy..." ${ }^{58}$. Rok później synod odebrał aktorowi kompetencje gromadzenia dochodów Jednoty: „sumy zborowe i krescencje ich, iż przez rozmaite ręce przechodzą do PP. szafarzów, wielkie umniejszenie biora, przetoż decernit, żeby którekolwiek pieniądze dochodza, zaraz nie do P. aktora, ale do P. szafarza za wiadomościa pasterską oddawane były"59. Działo się to w czasie aktorstwa wspomnianego Mikołaja Bykowskiego i szafarstwa Henryka Monesa. Wydaje się jednak, że z nowym aktorem - Janem Golimontem - Monesowi układało się lepiej, bo

${ }^{50}$ BLAN, f. 40, sygn. 1136, kanon 4 z 1641 r.

${ }^{51}$ Tamże, kanon 21 z 1642 r. Gierlicz żonaty był z luteranka, Katarzyną z Rejchowiczów, wdową po Antonim Szeferze; Testamenty w księach miejskich wileńskich $z$ XVI $i$ XVII $w$. Katalog, oprac. K. Frejlich, Warszawa 2017, s. 34.

${ }^{52}$ BLAN, f. 40, sygn. 1136, kanon 14 z 1652 r.

53 Tamże.

${ }^{54}$ Tamże; BLAN, f. 40, sygn. 1136, kanon 5 z 1654 r.; tamże, Memorialia, pkt 23 z 1654 r.

55 Tamże, kanon 5 z 1655 r.

${ }^{56}$ Akta synodów prowincjalnych... 1611-1625, s. 101; Akta synodów prowincjonalnych... 1626-1637, s. 26, 41, 61, 73, 84, 98, 137.

57 BLAN, f. 40, sygn. 1136, kanon 17 z 1647 r.

58 Tamże, kanon 15 z 1650 r.

59 Tamże, kanon 15 z 1651 r. 
w 1655 r. synod, przedłużając obu kadencję, zaznaczył, że liczy, iż szafarz nadal, jak dotąd, „z JMP aktorem czule i wiernie koło spraw Kościoła Bożego będzie chodził"60.

Pewną pomoca aktorowi zborowemu miały służyć doraźnie powoływane komisje do zrewidowania spraw poszczególnych zborów. Nie ponosiły one bezpośredniej odpowiedzialności finansowej w związku ze swoja działalnościa, ale miały dokonywać rozpoznania, oceny i raportowania o stanie ekonomicznym lub prawnym określonych parafii, zborów, elementów ich majątku czy obiecanych legatów. Komisje takie składały się zazwyczaj ze świeckich seniorów szlacheckich, ale udział w nich brał również superintendent dystryktu, na terenie którego leżał dany zbór; czasem także sam aktor zborów Wielkiego Księstwa Litewskiego. Jako przykład ciagnących się przez dziesięciolecia problemów, które rozpoznawać miały podobne gremia, można podać zbór w Szwabiszkach i majętności do niego należące. Dobra szwabiskie zostały zapisane Jednocie Litewskiej przez bezdzietnego Marcina Szwaba. Jednak pretensje do nich zgłosił domniemany potomek ofiarodawcy (Mikołaj Szwab vel Szwaba) i w ten sposób wspólnota ewangelicko-reformowana wciagnięta została, od $1611 \mathrm{r}$., w serię procesów o legowane dobra ${ }^{61}$. Ostatecznie majętność pozostała przy zborze, ale Jednota i kolejni opiekunowie zboru szwabiskiego wciąż mieli z nią kłopoty. Po śmierci Mikołaja Wizgierda, podkomorzego upickiego ${ }^{62}$, patronem majętności szwabiskiej był m.in. Krzysztof Radziwiłł, który w 1622 r. prosił synod, by to gremium zdecydowało, co robić z majętnością szwabiska, która była „szarpana od przeciwników”, a on sam dłużej już „nie chciał tego kłopotu dźwigać"63. Synod do kwestii szwabiskiej odniósł się jednak dopiero w 1625 r. (kanon 6), uzupełniając pomniejszony, na skutek śmierci niektórych z nich, zastęp opiekunów zboru ${ }^{64} \mathrm{i}$ już w następnym roku zarzą-

60 Tamże, kanon 5 z 1655 r.; tamże, kanon 5 z 1654 r.

${ }^{61}$ Bardziej szczegółowo opisuje sprawę Szwabiszek monografia rodziny Ciechanowieckich oraz Urszula Augustyniak; Dzieje rodziny Ciechanowieckich herbu Dabrowa (XIV-XXI wiek), red. A. Rachuba, Warszawa 2013, s. 64 n.; U. Augustyniak, Testamenty ewangelików reformowanych $w$ Wielkim Księstwie Litewskim $w$ XVI-XVIII wieku, wyd. 2 popr. i rozsz., Warszawa 2014, s. 106.

${ }^{62}$ Zmarł w 1622 r.; U. Augustyniak, Testamenty..., s. 105.

${ }^{63}$ Akta synodów prowincjalnych... 1611-1625, s. 72 (Pamięć xdzu Bańkowskiemu $z$ doctorem, o co się maja na synodzie starać).

${ }^{64}$ Tamże, s. 99. Szwabiszki stanowiły przykład legatu przynoszącego dyskusyjne korzyści, co wynikało z licznych procesów wszczynanych przez spadkobierców, czy w tym przypadku - domniemanych spadkobierców osób legujących dane dobra czy sumy. O problemie wspominamy niżej, a rozwiniemy go w osobnym artykule poświęconym legatom. 
dzono rewizję dla „niewiadomości rozrządzenia” majętności szwabiskiej, w skład której wchodził superintendent zawilejski Jan Minwid, aktor Józef Pietkiewicz, wojski upicki Krzysztof Spaski, Eliasz Rymwid i Jan Mikoszewski. Komisja miała ,jako najpilniej, w prowenta i ekspensa tameczne [szwabiskie - ML, PG] wejzrzawszy porządnie wszytko rozprawiwszy, na przyszłym, da Bóg, Synodzie [w 1627 r.] dostateczną relację [...] Zborowi Bożemu uczynić" ${ }^{65}$. Komisja najwidoczniej się nie zebrała, gdyż w kolejnych latach $\left(1627^{66}, 1628^{67}, 1629^{68}\right)$ ponawiano prośbę o podjęcie przez nią pracy. W 1634 r. proszono, choć w tonie upominania, aby seniorowie Szwabiszek co roku odbierali sprawozdania finansowe od ekonoma dóbr szwabiskich i pilnowali realizacji legacji fundatora zboru, Marcina Szwaba ${ }^{69}$, a w 1636 r. kolejna komisja, składajaca się z superintendenta zawilejskiego Aleksandra Bitowta i pana Koszkiela ${ }^{70}$, otrzymała zadanie ponownego zrewidowania majętności i puszczenia jej w trzyletnią arendę ${ }^{71}$. W kolejnych latach $\left(1637^{72}, 1638^{73}, 1639^{74}\right)$ gremium „szwabiskie” załatwiało kwestię dzierżawy majętności zborowej. Już w dwa lata później sprawa zboru i majętności szwabiskiej znowu zaprzątała synod: w 1641 r. zaktualizowano gremium opiekunów Szwabiszek $^{75}$, a w 1642 r. synod nakazał komisji szwabiskiej przedłużenie arendy Koszkielowi z jednoczesna rewizją postanowień umowy dzierżawnej ${ }^{76}$. Rok 1643 przyniósł konflikt z potomkiem fundatora o granice majętności szwabiskiej ${ }^{77}$, a później poddani tej majętności doświadczyli nieszczęścia pożaru, więc w $1645 \mathrm{r}$. synod zwolnił ich z wszelkich powinności ${ }^{78}$, jednocześnie nakazując zrewidowanie inwentarza Szwabiszek, pomniejszonego o wpływy z tych powinności. W 1649 r. synod

${ }^{65}$ Akta synodów prowincjonalnych... 1626-1637, s. 4, 6.

${ }^{66}$ Tamże, s. 25.

67 Tamże, s. 38.

68 Tamże, s. 51.

69 Tamże, s. 120.

${ }^{70}$ Koszkiel był darczyńca zboru w Kiejdanach. Być może chodziło tu o Jerzego Koszkiela, poborcę czopowego w powiecie upickim w 1643 r.; G. Błaszczyk, Herbarz szlachty żmudzkiej, t. 3, Warszawa 2015, s. 222.

${ }^{71}$ Zyski z niej miały posłużyć zaopatrzeniu potrzeb zboru szwabiskiego, a pozostałe środki miały być oddane do rąk aktora zborowego; tamże, s. 152.

72 Tamże, s. 167.

${ }^{73}$ BLAN, f. 40, sygn. 1136, kanon 27 z 1638 r.

${ }^{74}$ Tamże, kanon 8 z 1639 r.

75 Tamże, kanon 14 z 1641 r.

76 Wówczas też odmówiono prośbie potomka fundatora Szwabiszek o zgodę na sprzedaż majętności; tamże, kanony 11 i 17 z 1642 r.

77 Tamże, kanon 6 z 1643 r.

78 Tamże, kanon 4 z 1645 r. 
znowu uzupełnił - do dziewięciu - liczbę patronów Szwabiszek po śmierci niektórych poprzednich ${ }^{79}$. Znalazł się wśród nich m.in. Hieronim Puzyna, marszałek upicki, aktywny działacz kalwiński i hojny darczyńca zboru w Linkowcu ${ }^{80}$, z którym w roku następnym superintendent zawilejski miał kończyć transakcję w sprawie „różnic gruntów i sianożęci niektórych”81. Sprawa jednak nie była łatwa, a spory ciagnęły się jeszcze w drugiej połowie XVII w. Napięta sytuacja polityczna i okres wojenny w latach 50. sprawiły, że w następnych latach nie odnoszono się do problemu szwabiskiego i dopiero w 1659 r., na konwokacji kiejdańskiej, o pomoc w uporządkowaniu kwestii dotyczacych praw do majętności szwabiskiej i w jej odzyskaniu proszono księcia koniuszego litewskiego Bogusława Radziwiłła ${ }^{82}$. Nie był to jednak jeszcze sprzyjający moment na takie działania, co przyznano w 1660 r. i odłożono je do czasu, kiedy „książę koniuszy majętności swoje dziedziczne w posesję odbierać będzie, przy których Szwabiszek jure patronatus rekuperowane" ${ }^{83}$. W 1661 r. uzupełniono liczbę patronów tego zboru, wśród których znaleźli się, oprócz Bogusława Radziwiłła, Aleksander Dąbski oraz Hieronim i Frydrych Puzynowie ${ }^{84}$, a także porządkowano sprawę finansów majętności szwabiskiej, z czego rozliczał się Krzysztof Papłoński ${ }^{85}$. W 1664 r. dzierżawę szwabiską powierzono Janowi de Saus ${ }^{86}$, potomkowi wspomnianego wcześniej Jakuba, szafarza zboru niemieckiego. Takiego szczegółowego rewidowania na przestrzeni pierwszej połowy XVII w. wymagało regularnie co najmniej kilka zborów, więc patroni wchodzacy w skład poszczególnych komisji mieli ręce pełne roboty. Jak wskazuje także przykład Szwabiszek, nie zawsze gremia takie zbierały się sprawnie i od razu po zaleceniu synodu.

79 Tamże, kanon 20 z 1649 r.

${ }^{80}$ H. Lulewicz, Puzyna Hieronim, w: PSB, t. 29, Wrocław 1986, s. 488.

81 BLAN, f. 40, sygn. 1136, kanon 9 z 1650 r.

82 AGAD, Archiwum Radziwiłłów, dz. VIII, sygn. 713, Konwokacja kiejdańska z 1659 r., kanon 13, k. 339v.

83 Tamże, Konwokacja kiejdańska z 1660 r., kanon 6, k. 343.

${ }^{84}$ Pierwszy z nich był synem, a drugi, występujący także z imieniem Mikołaj, bratem Hieronima Puzyny, zmarłego w 1655 r. marszałka upickiego; H. Lulewicz, Puzyna Hieronim...

${ }^{85}$ AGAD, Archiwum Radziwiłłów, dz. VIII, sygn. 713, Konwokacja kiejdańska z 1661 r., kanony 13 i 14, k. 350v.

${ }^{86}$ Tamże, Konwokacja kiejdańska z 1664 r., kanon 16, k. 375. 


\section{Dokumentacja}

W dokumentacji wytworzonej przez władze wspólnoty, która dotrwała do naszych czasów, nie istnieje jakiś jeden zwarty zespół rachunków prezentujących sytuację finansowa Jednoty Litewskiej jako całości ani też jej poszczególnych zborów. W niniejszym artykule wykorzystane jednak zostana zachowane wyjątkowo pojedyncze księgi rachunkowe i inwentarze zborów, a także zapisy o legatach, beneficjach i rozliczeniach finansowych ujęte w aktach synodów prowincjonalnych.

Lektura tych ostatnich wskazuje, że jednym z głównych wyzwań organizacyjnych Jednoty było scentralizowanie jej administracji finansowej i zgromadzenie $\mathrm{w}$ archiwum wileńskim dokumentacji potwierdzającej prawa własności do świątyń i gruntów, a także uposażenia oraz legaty wszystkich zborów litewskich. W 1616 r. nakazano: „Spisanie zborów, ministrów i prowentów w każdym dystrykcie każdego superintendenta", która to dokumentacja miała być dostarczona na kolejny synod $^{87}$. W uzasadnieniu napisano: „Fundacje wszelkie, iż się dwojako czynią: jedne do podawania Zboru Wileńskiego, a drugie na potomki fundatorów zostawowane bywaja; postanowiono, aby pierwsze oryginały same do Zboru Wileńskiego do schowania, drugie same oryginały przy potomkach zostawiwszy, wypisy ich także do zboru wileńskiego oddawane były"s8. Wprowadzenie w życie tego nakazu napotykało jednak opory. Musiało ono być potwierdzone rok później ${ }^{89}$, a w 1619 r. przy okazji postanowienia o uporządkowaniu akt synodowych napisano również: „A osobliwie przywileje, fundusze, legata potrzeba, aby były zebrane, zrewidowane, zarejestrowane, w księgi wpisane i za wiadomością Pana Aktora, seniorów wileńskich mają być chowane"90. Podobny punkt znalazł się w aktach synodowych z 1624 r. i w kanonie De libro beneficiorum: „aby wszytkie legata beneficiorum secundum annos et tempora porządnie spisane w jedne księgi były. Które na każdym synodzie od ks. Superintendenta wileńskiego, przy którym być maja. A to dla prętszej wiadomości dościa in materiis controversi quod beneficia i dla rachunków każdorocznych proventów wszystkich zborów W.X. litewskiego" ${ }^{1}$. Wynika z niego, że co prawda wciąż nie sporządzono inwentarza funduszy i legatów, ale istniała tradycja corocznego sporządzania rozliczania finansowego przed synodem, jeszcze zanim w latach 40. pojawiły się

\footnotetext{
${ }^{87}$ Akta synodów prowincjalnych... 1611-1625, s. 36.

88 Tamże, s. 38.

89 Tamże, s. 41.

90 Tamże, s. 52.

91 Tamże, s. 88.
} 
wyżej opisane formalne przepisy wymagające takiego bilansu od aktora i szafarza. Regularnie przypominano o dostarczeniu do archiwum wileńskiego tzw. funduszów, a więc dokumentów potwierdzających ufundowanie - przekazanie pewnych sum pieniędzy, dóbr czy dochodów z dóbr, a także innego materialnego wsparcia, a w 1638 r. dobitnie jeszcze raz zaznaczono konieczność sporządzenia liber beneficiorum: „Aby tedy cośmy in votis zawsze mieli skutek swój tandem odnieść mogło; negotium hoc dexteritati P. aktora i ks. Jurskiego ${ }^{92}$ zlecamy, aby privilegia, fundationes et alia id genus beneficia porządkiem swym jako uczynione sa, zordynowali i w księgę pomienioną przystojnie wpisali" ${ }^{33}$. Monity te przyczyniły się do stworzenia właśnie około 1638 r. przez aktora Józefa Pietkiewicza (przy współpracy z duchownymi: Janem Jurskim i Stefanem Rudzikiem) ${ }^{94}$ specjalnej księgi nazywanej w aktach synodowych Metryką spraw i funduszów zborów Wielkiego Księstwa Litewskiego ${ }^{95}$. Szczęśliwie zachowała się ona do naszych czasów i jest przechowywana Litewskiej Bibliotece Narodowej ${ }^{96}$, i wydaje się, że można ją uznać za próbę realizacji zalecenia o sporządzaniu księgi beneficjów. Nie wydaje się jednak, że było ono wykonywane później (nie zachowały się dokumenty podobne do Metryki Pietkiewicza). Dopiero w 1668 r. na kartach protokołu synodalnego zestawiono „Sumy dystryktowe Zborów Wielkiego Księstwa Litewskiego". Niestety, wpisano tylko dane z czterech dystryktów (żmudzkiego, nowogródzkiego, zawilejskiego i ruskiego), na informacje z dystryktów wileńskiego i podlaskiego pozostawiając puste miejsce ${ }^{97}$. Widocznie nawet taki jednorazowy wysiłek sprawiał trudności i przekraczał możliwości egzekucyjne synodu prowincjalnego. Troska o uporządkowanie spraw finansowych widoczna jest także w przypadku samego zboru wileńskiego. W 1641 r. nakazano, by ministrowie wileńscy odzyskali u swych poprzedników „księgę metryk i spraw sesjalnych”98

${ }^{92}$ Ksiądz Jan Jurski był w tym czasie konseniorem zboru wileńskiego i jego kaznodzieją, a następnie objął zbór w Słucku; BLAN, f. 40, sygn. 1136 (podpisy na protokole z 1638, 1639 i 1640 r.).

93 Tamże, kanon 1 z 1638 r.

94 Tamże.

95 BLAN, f. 40, sygn. 1136, Memorialia, pkt 9 z 1642 r.; tamże, pkt 1 z 1644 r.

${ }^{96}$ Litewska Biblioteka Narodowa im. M. Mažvydo w Wilnie (dalej: LBN), f. 93, sygn. 1, Metryka albo spisanie spraw wieczystych, przywilejów, listów, zapisów i wypisów z różnych ksiag trybunalskich, ziemskich i grodzkich z rożnych woiewództw y powiatów w W. X. L. będących na zbór wileński y na insze Kościoły w W.X.L. (dalej: Metryka).

97 BLAN, f. 40, sygn. 1136, Sumy dystryktowe zborów W. X. Litt. z 1668 r., k. 304-306. Sumy dystryktu wileńskiego spisano w 1674 r.; BLAN, f. 40, sygn. 168, k. 59.

98 Tamże, Memorialia, pkt 1 z 1641 r. 
(która to prośbę ponowiono w roku następnym ${ }^{99}$ ), a w 1643 r., być może na skutek niepowodzeń poszukiwań dotychczasowej metryki, synod z kolei nakazał: „Sporządzenie sum przychodów od nich zborowi właśnie wileńskiemu należących", którym mieli się zająć superintendenci wileński i nowogrodzki wraz aktorem, aby móc zaprezentować taki sumariusz na kolejnym synodzie ${ }^{100}$. Z opisu zadania wynika, że jego wykonawcy mieli mieć do dyspozycji „rejestra Panów aktorów przeszłych"101. Z kolei synod z 1644 r., definiując zadania aktora, nakazał sporządzenie inwentarza wszystkich sum „wyderkaufowych i obligowych”, a także „kamienic, domów i placów”, aktualizowanego co roku i prezentowanego synodowi ${ }^{102}$.

Na wzór dokumentacji centralnej lub stołecznego zboru wieleńskiego miała powstawać dokumentacja poszczególnych zborów w postaci sumariusza zapisanych funduszy i legatów, udzielonych pożyczek oraz inwentarzy plebanii czy związanych z nimi dóbr. Miały się one znajdować pod opieka seniorów konkretnych zborów i superintendentów poszczególnych dystryktów ${ }^{103}$ albo zostać przekazana do archiwum do Wilna, jak szczegółowo opisuje to instrukcja dla zboru mińskiego z 1643 r. ${ }^{104}$ lub kanon 6 z 1648 r.: „Dla uwarowania wszelkich inkoweniencyjej, gdy munimenta i fundusze po różnych miejscach bywaja chowane, sancta decernit Synodus, aby autentyk funduszu ad archiwum zboru wileńskiego był oddany, a onego kopia przy zborze owym zachowana, a mianowicie spraw zboru mińskiego, funduszu szkoły kiejdańskiej i zboru szydłowskiego" ${ }^{05}$. Dążenie do kontroli i scentralizowania, jeśli nie samych finansów zborów, to przynajmniej dokumentacji kościelnej, widoczne jest również w kanonie 25 z 1649 r., nakazującym superintendentom zinwentaryzowanie wszystkich środków pieniężnych, jakimi dysponuja poszczególne zbory i zaprezentowanie inwentarzy na kolejnym synodzie prowincjonalnym ${ }^{106}$. Widocznie zbieranie dokumentacji, tak potrzebnej w prowadzeniu spraw procesowych, nie odbywało się sprawnie, dlatego kanonem $8 \mathrm{w} 1651 \mathrm{r}$. zdecydowano o pilnym gromadzeniu ich w Wilnie ${ }^{107}$.

\footnotetext{
99 Tamże, Memorialia, pkt 11 z 1642 r.

100 Tamże, kanon 9 z 1643 r.

101 Tamże.

102 BLAN, f. 40, sygn. 1136, kanon 1 z 1644 r.

103 Tamże, kanon 10 z 1644 r.; tamże, kanon 19 z 1645 r.; tamże, kanon 25 z 1649 r.

104 Tamże, kanon 10 z 1643 r.

105 Tamże, kanon 6 z 1643 r.

106 Tamże, kanon 25 z 1649 r.

107 Tamże, kanon 8 z 1651 r.
} 
Warto dodać, że dzięki dociekliwości synodu w jego aktach zachowały się pojedyncze rozliczenia szafarzy i aktorów, jak np. z 1652 r. („Weryfikacja rachunków szafarskich") ${ }^{108}$.

\section{Finanse}

Podstawę materialną i finansową funkcjonowania kalwińskiej wspólnoty wyznaniowej oraz jej dochodów stanowiły prywatne fundacje zborów, legaty pieniężne i rzeczowe (majątki ziemskie, nieruchomości na terenie miast, przedmioty srebrne i złote, naczynia liturgiczne itp.) ofiarowane przez członków Kościoła, a także organizowane przez Jednotę kolekty, czyli zbiórki pieniędzy wśród wiernych na różne cele. Te ostatnie ordynowane były przez synod prowincjonalny w razie konieczności wspomożenia przez członków konkretnych przedsięwzięć, np. szkół czy znajdujących się w potrzebie współwyznawców spoza granic Wielkiego Księstwa Litewskiego i dystryktu podlaskiego. Część pieniędzy na cele poszczególnych kolekt zbierano już w trakcie synodu, jednak większość datków spływała na ręce ministrów kwestujących w konkretnych zborach, a następnie superintendentów nadzorujących zbiórki w dystryktach. Na kolejnym, najbliższym synodzie prowincjonalnym przedstawiali oni zebrane kwoty, a synod decydował, czy zostaną spożytkowane zgodnie z pierwotnym przeznaczeniem, czy np. pomoga rozwiąać inny, bieżący problem (zob. niżej, podrozdz. Kolekty na drogę toruńska i egzulantów). Kasę Jednoty zasilały także zyski z zarządzania majątkiem nieruchomym (arend folwarków, wynajmu kamienic) oraz obracania kapitałem. Osoby pełniące wspomniane wyżej funkcje aktora zborowego oraz szafarzy nie zawsze jednak były w stanie poradzić sobie z właściwym zarządzaniem majątkiem Jednoty. Trzeba podkreślić, że obiektywnie nie było to łatwe zadanie ze względu na niesprzyjające okoliczności, związane m.in. z akcją rewindykacyjną prowadzoną przez Kościół katolicki, nasilającymi się konwersjami na katolicyzm dotychczasowych patronów poszczególnych zborów lub ich potomków, wymieraniem linii kalwińskich poszczególnych rodów itp. Czasem jednak słabym punktem były umiejętności aktorów zborowych i szafarzy, często zdarzały się też problemy z egzekucją darowizn, niekiedy zaś wpływ na kondycję finansowa Jednoty miała postawa najznaczniejszych jej członków - patronów generalnych (Radziwiłłów) i prowincjonalnych oraz opiekunów konkretnych zborów - lub duże wysiłki finansowe związane z koniecznością

108 Tamże, kanon 15 z 1652 r. 
uczestnictwa w ważnych, ogólnokrajowych wydarzeniach religijnych (Colloquium Charitativum w Toruniu w 1645 r.).

$\mathrm{Na}$ obecnym etapie badań nie jesteśmy w stanie zrekonstruować finansów całej Jednoty litewskiej ani szczegółów dotyczących kondycji ekonomicznej poszczególnych zborów. Jednak dzięki informacjom zawartym w aktach obrad synodów wileńskich oraz zachowanych pojedynczych rachunkach i dokumentach możliwe jest zestawienie danych o pewnych problemach ekonomicznych, które można uznać za symptomy kryzysu lub przynajmniej niewydolności aparatu administracyjnego. Wśród nich w niniejszym tekście omówiona zostanie kwestia finansów zboru wileńskiego, defraudacji, jakich dopuszczali się urzędnicy wspólnoty, sposobów wykorzystania zbieranych przez ewangelików kolekt, negatywnej weryfikacji szeroko zakrojonych planów edukacyjnych oraz trudności w egzekucji legatów.

\section{Zbór wileński}

Zbór wileński był najważniejszym spośród wszystkich wspólnot litewskich i bez wątpienia należał do dysponujących największym majątkiem nieruchomym (kilka kamienic i folwark) i obracał największymi środkami pieniężnymi. Z akt synodowych możemy się dowiedzieć, że w 1614 r. powołano tzw. ekonomię zborowa, a więc kamienicę darowana zborowi przez Jana Świrskiego zamieniono na mieszkania i stołówkę dla uczniów oraz nauczycieli szkoły zborowej, którymi miał zarządzać ekonom ${ }^{109}$. W 1616 r. podjęto wobec niej pewne decyzje, których nie wpisano do akt synodowych, choć pozostawiono na to w nich miejsce $^{110}$. Nie wydaje się jednak, że powstała jakaś trwała zwarta struktura organizacyjna, której najważniejszą częścią miała być szkoła, a obejmująca większy majątek i działalność Kościoła ewangelickiego w Wilnie. Funkcjonujący więc w ramach Jednoty szafarz zboru wileńskiego zarządzał kwestiami finansowymi wielu działających niejako oddzielnie instytucji ewangelickich, wśród których była szkoła, zbór, kamienice zborowe, cmentarz i w jakimś stopniu nawet szpital, który miał co prawda oddzielnego szafarza, ale pewne środki przepływały do niego przez ręce szafarza głównego. Dzięki zachowanym rachunkom szafarza Łukasza Bossy, prowadzonym od połowy 1623 do połowy 1625 r., możliwe jest zrekonstruowanie przychodów i wydatków związanych

\footnotetext{
${ }^{109}$ Akta synodów prowincjalnych... 1611-1625, s. 26-27.

110 Tamże, s. 39.
} 
Wykres 2. Struktura wpływów do skarbu szafarza zboru wileńskiego Łukasza Bossy od połowy 1623 do połowy $1625 \mathrm{r}$.

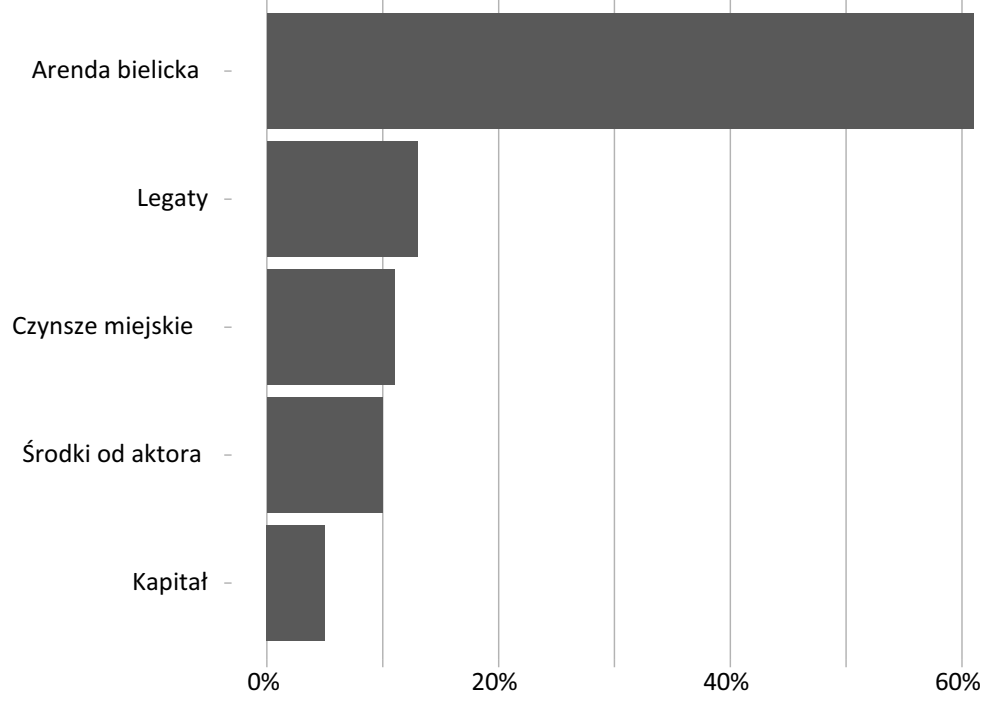

Źródło: oprac. własne na podstawie: BLAN, f. 40, sygn. 157.

z majątkiem i działalnością ewangelików reformowanych w Wilnie (zob. wykres 2) ${ }^{111}$. Przez dwa lata do rąk szafarza wpłynęło około 4575 zł z pięciu różnych źródeł. Pierwsze z nich (10\%) stanowia pieniądze (472 zł) przekazane przez aktora zborowego Pawła Progulbickiego i jego koadiutora Józefa Pietkiewicza z nadwyżki pozostałej po poprzednim roku oraz środki przeznaczone docelowo na utrzymanie straży zborowej. Drugie źródło przychodów (13\%) związane było z różnego rodzaju legatami i darowiznami przekazanymi do rąk szafarza w wysokości $581 \mathrm{zł.}$ Kolejne 506 zł wygenerowały czynsze z kamienic zborowych wynajmowanych na mieszkania i sklepy (11\%). Z kolei odsetki od kapitału, jaki była dłużna za kamienice zborową kniahini Massalska wynosiły 216 zł, czyli 5\% przychodów. Bez wątpienia najważniejszym źródłem wpływów była jednak tzw. arenda bielicka, dająca w ciagu dwóch lat aż 2800 zł, czyli $61 \%$ wszystkich przychodów. Wydaje się też, że to źródło było stabilne, w przeciwieństwie do trudno ściagalnych czynszów z wynajmowanych przez wspólnotę budynków. Rachunki wskazuja na problemy nawet z zamieszkującymi je rodzinami duchownych. Łukasz Bossa pisze o „Pani Welsjuszowej” (zapewne żonie pastora Andrzeja Welsjusza, nieżyjącego już kaznodziei niemieckiego zboru w Wilnie), która kłóciła

${ }^{111}$ BLAN, f. 40, sygn. 157. 
się z szafarzem „z wielkim gniewem i frasunkiem”, a będący świadkiem wydarzeń aktor Józef Pietkiewicz „tylko się śmiał, hamując ją"112. Z kolei inny szafarz - Jan Grekowicz - zeznał przed sądem w 1654 r., że czeladzi Jana Łomskiego, który nie chciał zapłacić za wynajmowana od zboru kamienicę, nakazano, „aby Pana Grekowicza znieważyli, potłukli, pobili i pokaleczyli”"113.

W 1621 r. synod, obawiając się tumultu, zdecydował „o dalszym obwarowniu murem i wynajęciu straży Zboru Wileńskiego"114. Łatwiej było jednak podjąć taką decyzję, niż wprowadzić ją w życie. Problemem były oczywiście pieniądze, dlatego przeprowadzono celową zbiórkę: „Przeto Ich M. Panowie Patronowie i inszy auditorowie, którzy się na ten synod zgromadzili, summę pieniędzy, jako komu Pan Bóg do serca podać raczył, złożyć obiecali i spisać się raczyli, a drudzy już i oddali do skrzynki zborowej"115. Środków nie było jednak chyba dużo, gdyż aktor zborowy Paweł Progulbicki, jak zapisano w dalszej części protokołów, „postanowił dawać na straż Zboru Wileńskiego na każdy rok po dziesięciu kop litewskich"116. Kolekta zebrana na zbór wileński w 1623 r. była chyba bardziej udana, a w dodatku donatorzy zostali zapisani w aktach synodowych. Spośród nich dwóch: Jan Frąckiewicz Radzimiński, chorąży lidzki, obiecał na piechotę 50 zł, a Dawid Narownik dał 4 czerwone złote $(20 \mathrm{złp})^{117}$. Z zachowanych rachunków Łukasza Bossy wynika, że straż zborową w 1623 r. tworzyło pięciu zbrojnych i ich dziesiętnik (który według synodu nie powinien być nazywany kapitanem, a właśnie dziesiętnikiem $)^{118}$. Ich roczne wynagrodzenie wynosiło około $300 \mathrm{zł}$, ale do tego trzeba doliczyć ponad $100 \mathrm{zł}$ na materiały i krawca do uszycia specjalnych ubrań, a także inne elementy związane z ich utrzymaniem (narzędzia, drewno do ogrzewania itd.). Łącznie przez dwa lata na ochronę wydano 1003 zł, co stanowiło 24\% wszystkich wydatków zarejestrowanych w księdze rachunkowej Łukasza Bossy (około 4226 zł). Nieco więcej wydano na wynagrodzenie i utrzymanie ministrów - 1137 zł (27\%) i nauczycieli szkoły wraz niezbędnym wyposażeniem - 1233 zł (29\%). Około 853 zł, a więc 20\% wydatków

112 Tamże, k. 3.

${ }^{113}$ LBN, f. 93, sygn. 1668.

114 Akta synodów prowincjalnych... 1611-1625, s. 64; szerzej o napiętej sytuacji w tym czasie zob. T. Kempa, dz. cyt., s. 332-334.

${ }_{115}$ Akta synodów prowincjalnych... 1611-1625, s. 64.

116 Tamże, s. 64-65.

117 Tamże, s. 83; Z. Żabiński, Systemy pieniężne na ziemiach polskich, Wrocław 1981, s. 115.

118 Akta synodów prowincjalnych... 1611-1625, s. 82. 
związanych było z utrzymaniem, remontami i obsługa majątku nieruchomego zboru wileńskiego (remonty, budowy, ogrzewanie, szpital), organizacją synodów i opłatami sądowo-skarbowymi (zob. wykres 3).

Wykres 3. Struktura wydatków szafarza zboru wileńskiego Łukasza Bossy od połowy 1623 do połowy $1625 \mathrm{r}$.

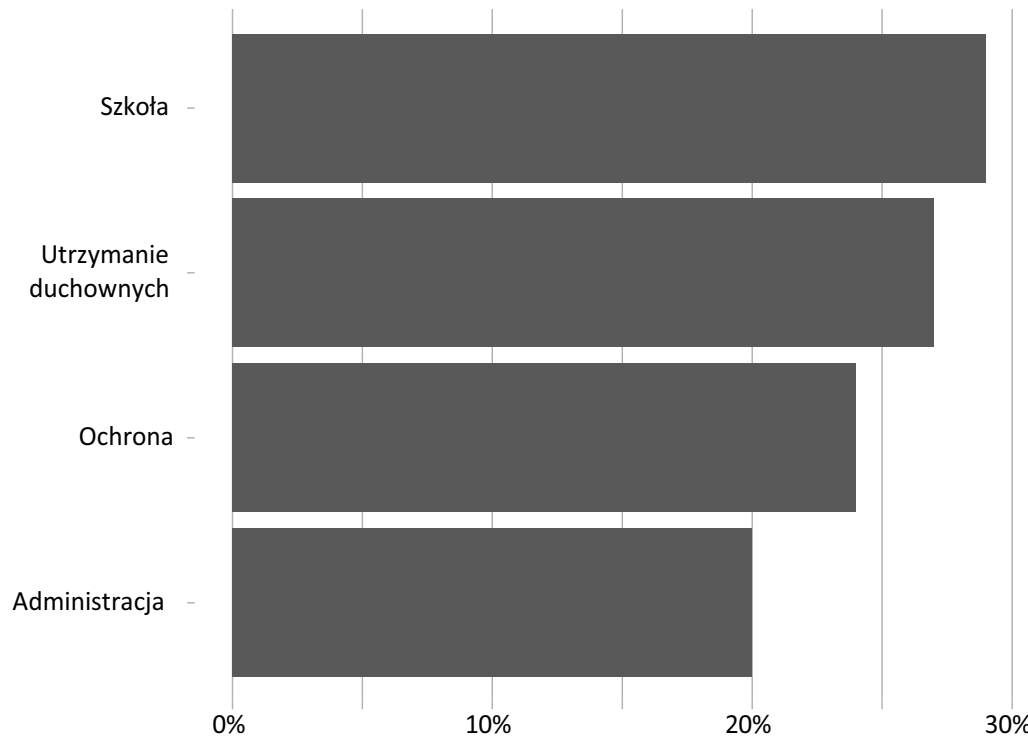

Źródło: oprac. własne na podstawie: BLAN, f. 40, sygn. 157.

Sześciu zbrojnych zborowych stanowiło więc poważne obciążenie budżetu wileńskiego, ale w momentach napięcia mogło nie wystarczyć. Dlatego wojewoda wileński książę Krzysztof Radziwiłł posyłał ewangelikom swoja straż wojewodzińską do pilnowania zboru. Niestety oni także obciążali finanse wspólnoty, co zostało zanotowane w rachunkach zborowych Łukasza Bossy ${ }^{119}$. Wiemy, że ewangelicy wileńscy utrzymywali zbrojną ochronę w kolejnych dekadach XVII w. W 1632 r. synod prowincjonalny wyznaczył zwierzchnikowi wachty zborowej - Jerzemu Wołodkiewiczowi - pensję 70 florenów ${ }^{120}$, a jednego ze zbrojnych - Mikołaja Szabłowskiego, który „na posłudze zborowej zdrowia naruszy”” przyjęto w 1638 r. do szpitala wileńskiego ${ }^{121}$. W tym samym czasie w dokumentacji synodu partykularnego wileńskiego odnotowano

119 BLAN, f. 40, sygn. 157, k. 8v.

${ }^{120}$ Akta synodów prowincjonalnych... 1626-1637, s. 98.

121 BLAN, f. 40, sygn. 1136, kanon 22 z 1638 r. 
petycje wartowników o zwiększenie liczby zbrojnych do $8^{122}$. Mimo ciągłej obecności zbrojnych w zborze stosunkowo niewiele uwagi poświęcono im zarówno w relacjach źródłowych o wydarzeniach październikowych 1639 r., kiedy to zbór został zaatakowany, jak też w literaturze dotyczącej tumultu ${ }^{123}$. Z rekonstrukcji przebiegu konfliktu przeprowadzonej przez Bogumiła Zwolskiego wynika, że 5 X 1639 r., kiedy nastapił pierwszy atak tłumu na zbór: „Straż zborowa w czas się spostrzegła i zamknęła bramy, o zdobycie których napastnicy daremnie się kusili”" ${ }^{124}$. Także drugiego dnia zbór nie został zdobyty, ale historycy opisujący wydarzenia wileńskie wspominaja jedynie zazwyczaj udział wojska przysłanego do ochrony zboru przez wojewodę. Urszula Augustyniak zauważyła jednak słusznie, że w swoich relacjach przeciwnicy ewangelików notorycznie, zapewne z powodów propagandowych, nazywają żołnierzy wojewodzińskich (formalnie zaś królewskich) zborowymi, choć obie formacje musiały różnić się wyraźnie strojem ${ }^{125}$. Wydaje się, że straż zborowa, obciążajacca finanse wspólnoty wileńskiej, spełniła swoją powinność, zbór nie został zajęty, a splądrowano jedynie szpital i szkołę. Pieniądze zainwestowane w ochronę okazały się dobrą inwestycją i w kolejnych latach dalej utrzymywano strażników, o czym świadczy zapis w aktach synodu z $1654 \mathrm{r}$. drobnego legatu na „wartę zborową"126.

\section{Lukasz Bossa i kłopoty zboru wileńskiego}

Bilans działalności szafarskiej Łukasza Bossy, zamożnego mieszczanina $^{127}$ i seniora zboru wileńskiego, w świetle rachunków wydaje się dodatni, widoczna jest bowiem niewielka, ale jednak nadwyżka budżetowa. Analiza akt synodów prowincjonalnych pokazuje wszakże negatywne strony jego działalności na rzecz wspólnoty ewangelickiej.

${ }^{122}$ W. Gizbert-Studnicki, Suplement. Aneks nr. 3, w: H. Merczyng, Wilno ewangelickie, Wilno 1925, s. 10.

${ }^{123}$ B. Zwolski, Sprawa Zboru Ewangelicko-Reformowanego $w$ Wilnie $w$ latach 1639-41, Wilno 1936; H. Wisner, Likwidacja zboru ewangelickiego w Wilnie (1639-1646). Z dziejów walki z inaczej wierzacymi, „Odrodzenie i Reformacja w Polsce” 37, 1993, s. 89-102; U. Augustyniak, Jeszcze raz w sprawie tumultu wileńskiego 1639 i jego nastepstwach, „Odrodzenie i Reformacja w Polsce” 50, 2006, s. 169-189; T. Kempa, dz. cyt., s. 407-415.

${ }^{124}$ W. Zwolski, dz. cyt., s. 18.

${ }_{125}$ U. Augustyniak, Jeszcze raz $w$ sprawie..., s. 186.

126 BLAN, f. 40, sygn. 1136, Memorialia, pkt 19 z 1654 r.

127 Łukasz Bossa był m.in. właścicielem kamienicy w Wilnie; M. Paknys, Vilniaus miestas ir miestieciai 1636 m. Namai, gyventojai, sveciai, Vilnius 2006, s. 118, 230. 
W 1626 r. zanotowano: „Ponieważ P. Bossa jeszcze według kanonu takrocznego nie dosyć uczynił Zborowi Bożemu, przetoż P. aktor ma tego pilno dojźrzeć, aby nieodwłoczna satysfakcja od niego stać się mogła"128. O skali nieprawidłowości, jakich dopuścił się ten szafarz, świadczą kanony synodowe z kolejnych lat. Kanon 20 z 1627 r. informuje, że dług Bossy wobec zboru wileńskiego wynosił 180 kop groszy litewskich (360 zł), ale z racji małych szans na jego zwrot synod pozwolił „mu, aby murem ogród, gdzie ciała ewangelików chowane bywaja, za te pieniądze, póki ich zostawać będzie, obwodził"129. Niestety po obiecujących początkach i praca murarska dawnemu szafarzowi się nie udała, i w $1628 \mathrm{r}$. synod nakazał aktorowi starać się o zwrot długu (tym razem wyliczonego na 200 kop groszy litewskich, czyli 400 zł). W dodatku okazało się, że Łukasz Bossa „sumę 600 zł na alumny od ks. J.M. daną przy sobie zatrzymał"130, za co mu pogrożono karami kościelnymi. Nie był to pierwszy przypadek sprzeniewierzenia przez niego datków wiernych, gdyż już w 1625 r. synod był zaniepokojony, że jako szafarz wziął legat 80 kop na szpital i zbór wileński od mieszczanina ryskiego Bohdana Owsimowicza, ale nie przekazał ich kościołowi wileńskiemu ${ }^{131}$. Groźby kar sądowych i kościelnych nie przyniosły skutku, gdyż w 1630 r. synod prowincjonalny nakazał „publicam remotionem a Coena Domini”, co miało być ogłoszone „po bliższych zborach” ${ }^{132}$. Moc kary wykluczenia ze wspólnoty utrzymano w kolejnym roku ${ }^{133}$, ale dopiero w 1632 r. zlecono superintendentowi wileńskiemu jej wyegzekwowanie ${ }^{134}$. To ostatnie zalecenie wskazuje, że decyzje synodu prowincjonalnego były w jakiśs sposób sabotowane przez miejscową wspólnotę ewangelików, która mimo zdefraudowania środków przez Bossę wybierała go na seniora zboru wileńskiego w latach 1627 i $1628^{135}$. Mimo nakładania kar kościelnych na byłego szafarza zmarł on, nie rozliczywszy się ze swoim zborem i synod 1635 r. podjał decyzję, ,,aby J.M.P. aktor długu kop 300 po nieboszczyku P. Bossym zborowi wil[eńskiemu] pozostałego, poczekał tak długo, ażby suma za folwark, który małżonka pozostała i z potomstwem nieboszczykowskim od J.M.P. wojewody trockie[go] trzyma, rekuperowana

${ }_{128}$ Akta synodów prowincjonalnych... 1626-1637, s. 5.

129 Tamże, s. 26.

130 Tamże, s. 41.

131 Akta synodów prowincjalnych... 1611-1625, s. 101.

132 Akta synodów prowincjonalnych... 1626-1637, s. 73.

133 Tamże, s. 84.

134 Tamże, s. 98.

135 Tamże, s. 30, 44. 
była"136. Stało się to ostatecznie dopiero w 1637 r., gdyż w aktach synodowych zapisano informację, że suma „po śmierci Pana Bossego przez ks. Chociszewskiego ${ }^{137}$ z dóbr jego wróciła się"138.

Kłopoty finansowe zboru wileńskiego, spowodowane zapewne nie tylko przez Łukasza Bossę, niepokoiły synod prowincjonalny, który, jak już wspomniano, przydawszy w 1629 r. sześciu pomocników (trzech duchownych i trzech świeckich) aktorowi i koadiutorowi nakazał na Trzech Króli kolejnego roku sporządzić bilans, wydając wskazówki, „aby pieniężne sumy, a zwłaszcza główniejsze, nikomu nie pożyczali na obligi, tylko na zapis pewny na majętności pewnej i niezawiedzionej według prawa i obwarowanej. A te sumy, które tegoż za obligiem sa, aby ex nunc od Synodu tego na majętności wniesione były od tych, którzy pieniędzy naszych używali”139. Wydaje się, że działalność tej komisji i aktora Józefa Pietkiewicza przynosiły pozytywne skutki, skoro w aktach synodowych z 1637 r. odnotowano, że nadwyżka wpływów zboru wileńskiego przekraczała wydatki o 3 tys. zł. Dlatego zdecydowano się suma 2 tys. florenów wspomagać szkołę w Kiejdanach przez pięć lat (po 400 zł rocznie) ${ }^{140}$.

Ten pozytywny trend nie trwał długo. Już w 1638 r. synod wyznaczył specjalną komisję (z aktorem w składzie), której członkowie „we wszystkie gravamina zboru wileńskiego pilnie wejrzą i sposób wynajda, jakby im zabieżeć, żeby się napotym nie jawiły" ${ }^{141}$. Także tumult z $1639 \mathrm{r}$. i jego prawne konsekwencje ( $w$ tym prowadzone procesy) na pewno niekorzystnie wpłynęły na finanse zboru wileńskiego. Wiadomo np., że zebrana w 1639 i 1640 r. kolekta na pomoc dla wygnańców ewangelickich z Palatynatu została obrócona na „potrzeby zboru wileńskiego”142. W 1641 r. synod prowincjonalny nakazał superintendentowi wileńskiemu i aktorowi, „aby oni wziąwszy od Synodu patent wszystkich J.MM. PP. kredytorów Zboru Bożego obwieścili i aby sumy na terminach oddawali, upomnieli i około tych sum dextre et prudenter"143. Ten sam synod podjął dramatyczną decyzję: „domy, kamienice i place w mieście lub za miastem [...] za słuszną cenę spieniężyć pozwala, które to

\footnotetext{
136 Tamże, s. 137.

${ }^{137}$ Ksiądz Tomasz Chociszewski, późniejszy superintendent dystryku wileńskiego (1641-1652).

138 BLAN, f. 40, sygn. 1136, kanon 9 z 1638 r.

139 Akta synodów prowincjonalnych... 1626-1637, s. 53.

140 Tamże, s. 166.

141 BLAN, f. 40, sygn. 1136, kanon 8 z 1638 r.

142 Tamże, kanon 4 z 1640 r.

143 Tamże, kanon 4 z 1641 r.
} 
pieniądze na budynek zboru nowego i obmurowanie ogrodu pogrzebowego obrócone być maja" ${ }^{144}$. Co prawda po roku uznano, że akcję sprzedaży nieruchomości należy przerwać ${ }^{145}$, ale sytuacja zboru wileńskiego nie uległa poprawie. Akta synodu z 1643 r. mówia o „wielkim niedostatku i gorących potrzebach, które zachodzą zbór, szkołę i szpital wileńskie”, upominając się u Janusza Radziwiłła o spłatę odsetek od długu zaciagniętego u ewangelików ${ }^{146}$. Jednocześnie wspólnota sama pożyczyła 1 tys. florenów od superintendenta wileńskiego Tomasza Chociszewskiego na „zborowe potrzeby” ${ }^{147}$, a 850 zł u Andrzeja Żebrowskiego ${ }^{148}$. Trudności w zarządzaniu finansami i częste zmiany aktorów doprowadziły do wspomnianego na wstępie sprecyzowania obowiązków aktorskich w kanonie 1 z $1644 \mathrm{r}$., ale początkowo nie przyniosło to efektów. W świetle akt synodowych w 1646 r. nadal „zbór wileński względem ministrów wychowania, wdów sustentowania, budynków wystawowania i inszych potrzeb obmyśliwania wielkie patitur incomoda w niedostatku pieniędzy" i konieczne było zaciagnięcie kolejnej pożyczki, tym razem 1600 zł u aktora zborowego Krzysztofa Papłońskiego ${ }^{149}$.

Jednocześnie ewangelicy musieli zmierzyć się z niekorzystnym wyrokiem Trybunału Litewskiego w związku z przejęciem majętności Stary Dwór legowanej przez Aleksandra Kurmina, ale obciazżonej długami w wysokości aż 9 tys. zł, które miał spłacać superintendent Tomasz Chociszewski, zarządzający tymi dobrami prawem zastawu ${ }^{150}$. W $1649 \mathrm{r}$. akta synodów prowincjonalnych zanotowały informacje o nietrafionych inwestycjach budowlanych szafarza Jana Grekowicza ${ }^{151}$, a także długach zaciagniętych na rzecz wspólnoty przez aktora u seniorów zboru wileńskiego $(1550 \mathrm{zł})^{152}$. Synod prowincjonalny z $1650 \mathrm{r}$. rozpoczą się od wspomnianej wyżej skargi i zdyscyplinowania aktora Mikołaja Bykowskiego ${ }^{153}$. Ratunek w bieżących potrzebach przyszedł od rajcy Henryka Monesa, który pożyczył wspólnocie 2100 zł, za co otrzymał na trzy i pół roku jedna z kamienic zborowych ${ }^{154}$. Przejął on po Żebrowskim funkcję szafarza zboru wileńskiego. Akta synodu z 1652 r. notuja finansowe

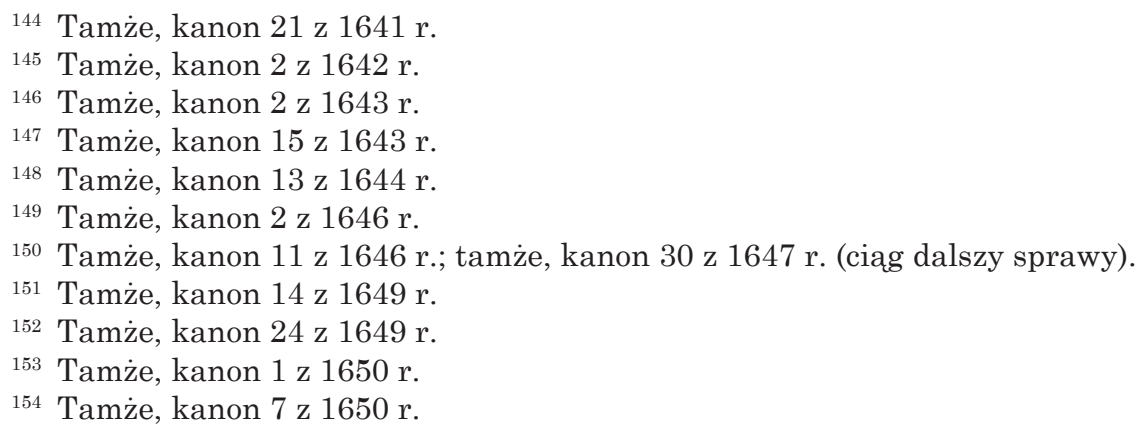


rozliczenie obu szafarzy ze swojej pracy. Żebrowski przedstawił rachunki, z których wynikało, że wpływy zboru wileńskiego były niewielkie, wynosiły nieco ponad 1030 zł, a wydatki je przekraczały (ponad 1222 zł). Różnicę Żebrowski pokrył z własnych środków i wspólnota była mu winna (łącznie z wcześniejszymi długami) niemal 600 zł. Zadziwiające jest, że nowy szafarz osiagnął nadspodziewanie lepsze wyniki. Według Monesa przychody zboru wileńskiego wyniosły 6193 zł, do których jeszcze można dodać 1193 zł z kolekty na mur. Zapisane w rozliczeniu wydatki były znacznie niższe - 3740 zł, ale nie zawierają informacji o wynagrodzeniu duchownych czy utrzymaniu szkoły. Mimo to możemy stwierdzić jakościową zmianę w zarządzaniu finansami, czego potwierdzeniem jest zadowolenie synodu ze współpracy szafarza Henryka Monesa z aktorem Janem Golimontem, wyrażone w protokołach synodalnych z lat 1654 i $1655^{155}$. Widocznym efektem odbudowy finansowej zboru wileńskiego jest udzielona przezeń pożyczka w wysokości 5 tys. zł na prośbę horodniczego wileńskiego Pawła Kleofasa Podchocimskiego. Wspólnota dysponowała środkami jeszcze wyższymi, gdyż zadeklarowała pożyczenie mu aż 8 tys. zł, ale z części jednak dłużnik zrezygnował ${ }^{156}$. Poprawie sytuacji materialnej zboru wileńskiego towarzyszyły jednak trudności finansowe i organizacyjne innych zborów dotkniętych działaniami wojennymi, grabieżą ze strony wojska oraz podatkami. Dlatego w przeddzień potopu synod prowincjonalny wezwał kościół wileński, by „te zbory, które do niego są inkorporowane, ratował"157.

\section{Kolekty na drogę toruńską i egzulantów}

W'́ród wydarzeń nadzwyczajnych, zajmujących szczególne miejsce w dziejach Jednoty Litewskiej w pierwszej połowie XVII w., znajduje się słynne toruńskie Colloquium Charitativum z 1645 r. Decyzja o przyjęciu zaproszenia królewskiego została podjęta przez ewangelików litewskich na synodzie w $1644 \mathrm{r} .{ }^{158}$, a synod w kolejnym roku wyznaczył delegatów. Wśród nich było siedmiu duchownych (w tym dwóch superintendentów: ks. Mikołaj Wysocki - podlaski i Andrzej Muzoniusz - nowogródzki), którym przeznaczono na utrzymanie po 100 zł na trzynaście

155 Tamże, kanon 5 z 1654 r.; tamże, kanon 5 z 1655 r.

156 Tamże, kanon 9 z 1654 r.; tamże, kanon 3 z 1655 r.

157 Chodziło o zbory należące do dystryktu wileńskiego; tamże, kanon 12 z 1655 r.

158 Tamże, kanon 22 z 1644 r. Pierwotnie kolokwium było planowane na 1644 r., ale jego termin został przesunięty o rok; zob. E. Piszcz, Colloquium Charitativum w Toruniu A.D. 1645. Geneza i przebieg, Toruń 1995. 
tygodni ${ }^{159}$. Aby zgromadzić środki, ogłoszono kolektę we wszystkich dystryktach ${ }^{160}$. Podczas synodu prowincjonalnego w 1646 r. delegatom podziękowano za relację $\mathrm{z}$ obrad toruńskich, a jednocześnie $\mathrm{w}$ związku z tym, że „de suo się musieli Kościoła Bożego na się włożonemu [obowiązkowi - ML, PG] dosyć czyniąc”, synod zapewnił, że „za te ekspensa skoro pieniądze od księcia JM dojda, ex publico aerario mają być refundowane"161. Chodziło o sumę 600 zł i 200 talarów ${ }^{162}$. Przekroczyła ona możliwości spłaty wspólnoty i w aktach synodu prowincjonalnego 1647 r. znajdujemy zapis: „Dług od braci ad colloquium charitativum delegowanych, w Toruniu zaciagniony, iż im na tym teraźniejszym Synodzie oddany być nie mógł, obietnicę czyni i asekuruje Zbór Boży, iż na przyszłym, da Bóg, Synodzie secundum specificam decisionem kanonu w roku przeszłym 1646 uczynionego ante omnes alios satysfakcję odniosa" ${ }^{163}$. Niestety, nie zwrócono tych prywatnie zaangażowanych w sprawy Kościoła ewangelickiego środków przez dwa kolejne lata i synod prowincjonalny z 1649 r. zmuszony był jeszcze raz prosić duchownych o cierpliwośćc ${ }^{164}$. Musiało jej wystarczyć na kolejne lata, bo akta synodowe z 1653 r. wspominaja, że delegatom na kolokwium nadal nie zwrócono poniesionych kosztów, choć po raz kolejny zapisano $\mathrm{w}$ tej sprawie zobowiazanie ${ }^{165}$. Zapewne nowy aktor wraz z szafarzem wileńskim, którzy podźwignęli finanse Kościoła ewangelickiego, zdołali ostatecznie spłacić stare długi, gdyż więcej informacja o nich nie pojawia się $\mathrm{w}$ aktach synodowych, ale historia niespłacanych przez lata zobowiązań w związku z jednym z najważniejszych wydarzeń religijno-politycznych tamtych czasów, którego znaczenia wspólnota ewangelicka była w pełni świadoma, jest symptomem głębokiego kryzysu finansów Jednoty Litewskiej od końca lat 30. do początku 50. XVII w.

Drugim dowodem na jego istnienie jest ewolucja skuteczności pomocy dla wygnańców ewangelickich, ofiar trwającej wojny trzydziestoletniej. W 1632 r. synod prowincjonalny zdecydował o zebraniu kolekty w celu „poratowania tej braciej, którzy dla prawdy i sprawiedliwości, to wygnanie i ten niedostatek cierpia”"166. Choć kanon mówi, że miała być zebrana na rzecz egzulantów z Palatynatu, dokumentacja kolejnego synodu pokazuje

159 BLAN, f. 40, sygn. 1136, kanon 1 z 1645 r.; tamże, Memorialia, pkt 26 z 1645 r.

160 Tamże, kanon 3 z 1645 r.

161 Tamże, Memorialia, pkt 6 z 1646 r.

162200 talarów to przy ówczesnym kursie 600 zł; zob. Z. Żabiński, dz. cyt., s. 110.

163 BLAN, f. 40, sygn. 1136, kanon 31 z 1647 r.

164 Tamże, kanon 16 z 1649 r.

165 Tamże, kanony 16 i 45 z 1653 r.

${ }^{166}$ Akta synodów prowincjonalnych... 1626-1637, s. 96. 
jednak, że 3500 zł z tego funduszu wysłano do Włodawy i Leszna, gdzie osiedlili się egzulanci z Czech ${ }^{167}$. Przy okazji jednak powtórzono wezwanie do podobnego wsparcia ewangelików niemieckich ${ }^{168}$, a nawet zarejestrowano 300 kop „na mury złożonych, a teraz na egzulany Superioris Palatinatus obrócone" 169 . Nie ma śladu bezpośrednio w kolejnych latach o zbiórkach tego typu, aż w $1637 \mathrm{r}$. w protokołach synodowych zanotowano dramatyczna relację „O braciej haidelberskiej”170, która wymaga natychmiastowej pomocy, a rok później synod rozliczył ks. Jurskiego z przesłanych do Niemiec pieniędzy ${ }^{171}$. Przez większość lat 30. Jednota nie miała więc problemów z zebraniem, jak nazywano w źródłach, „jałmużny”, która można było wysłać współbraciom w potrzebie. W $1640 \mathrm{r}$. zauważono jednak ,że kolekta na bracią analtyńską nie tylko dotychczas nie odesłana, ale też urgente necessitate na potrzeby zboru wileńskiego obrócona”. Synod prowincjonalny zażądał, by superintendent wileński przeprowadził nową zbiórkę i odesłał zebrane środki „ubogim egzulantom"172. Kolekty jednak nie udało się przeprowadzić i w kolejnym roku poproszono, by aktor z dochodów Jednoty wysłał odpowiednią sumę pieniędzy do Niemiec za pośrednictwem pastora Niklasjusza z Gdańska. Przy okazji okazało się, że zebrane na wygnańców środki użyto nie tylko na potrzeby zboru wileńskiego, ale część z nich pożyczono księciu Krzysztofowi Radziwiłłowi, który w międzyczasie zmarł173. Nie wiemy, czy pieniądze ostatecznie trafiły do ewangelików niemieckich, ale przedstawiciele Jednoty zgromadzeni na synodzie 1641 r. czuli wyrzuty sumienia z powodu rozdysponowania na inne cele środków zebranych dla cierpiących współbraci w wierze i dlatego podjęli próbę naprawy sytuacji, „bojąc się, aby nas Bóg ciężej za to nie karał”174.

\section{Pożyczki udzielane Radziwiłłom}

Dużym problemem Jednoty Litewskiej okazał się brak zabezpieczenia finansowego na trudny czas, który ewidentnie nastapił po tumulcie wileńskim 1639 r. Nie znaczy to jednak, że ewangelicy nie myśleli

\footnotetext{
167 Tamże, s. 108.

168 Tamże, s. 103.

169 Tamże, s. 109.

170 Tamże, s. 161-162.

171 BLAN, f. 40, sygn. 1136, Memorialia, pkt 13 z 1638 r.

172 Tamże, kanon 4 z 1640 r.

${ }_{173}$ Tamże, kanon 12 z 1641 r.

174 Tamże.
} 
o zagrożeniu kryzysem. Co więcej, mamy podstawy, by sądzić, że zgromadzili spore środki, których nie można było wykorzystać na bieżące potrzeby. Przyczynę tej niemożności wyjaśnia zapis Krzysztofa Radziwiłła w księgach trybunalskich wileńskich z 19 VI 1636 r.: „będąc ja potrzebny sumy pieniędzy wziałem gotowej rąk oddanej sumy czterdziestu i ośmiu tysięcy złotych polskich z własnej karbony zborowej u J.M.P. Józefa Pietkiewicza jako aktora [...] z konsensem i wiadomościa wszystkiego synodu prowincjonalnego"175. Od tej sumy Radziwiłł miał płacić rocznie czynszu 3360 zł w dwóch ratach, a pożyczka była zabezpieczona na dobrach kiejdańskich, bojnarowskich i mieleszkowskich ${ }^{176}$. Po śmierci Krzysztofa Radziwiłła w 1640 r. zobowiązania po nim przeją jego syn Janusz, ale już w $1643 \mathrm{r}$. synod prosił go o regularne płatności, ewentualnie oddanie w zastaw jakiejś kolejnej majętności, gwarantującej dopływ gotówki do skarbu Jednoty ${ }^{177}$. Mimo niewątpliwego wsparcia patronackiego ze strony podkomorzego i hetmana polnego Wielkiego Księstwa Litewskiego, Janusza Radziwiłła nie można uznać za rzetelnego partnera $\mathrm{w}$ rozliczeniach kredytowych $\mathrm{z}$ ewangelikami. Synod wileński z $1648 \mathrm{r}$. w kanonie 3 wskazuje na problemy z przekazywaniem Jednocie środków z dóbr kiejdańskich ${ }^{178}$, a także na pośrednictwo tamtejszych Żydów, którzy jednak zamiast pieniędzy przekazali jedynie obligi na nie ${ }^{179}$. W kolejnych latach zobowiązania finansowe Janusza Radziwiłła wobec ewangelików jeszcze się powiększały. O ich skali informuja zapisy akt synodu prowincjalnego z $1650 \mathrm{r}$. Według nich do dawnej pożyczki w wysokości 48 tys. zł należy dodać kolejne, na sumę 13250 zł, od których łącznie roczny czynsz powinien przynosić Jednocie 4277 zł i 15 gr (7\% rocznie) i ma być oddawany do zboru wileńskiego. Ponadto Janusz Radziwiłł, lub Żydzi kiejdańscy w jego imieniu, za niewypłacony czynsz z lat poprzednich wnieśli obligi na sumę 13600 zł, które miały być spłacone po trzech latach (bez odsetek). Pozostałe zobowiąania, które obiecał Janusz Radziwiłł ewangelikom uregulować „niepochybnie”, wynosiły $4992 \mathrm{zf}^{180}$. W bardzo trudnym więc pod względem finansowym dla Jednoty Litewskiej okresie kryzysu po tumulcie wileńskim 1639 r. najwięksi patronowie Kościoła ewangelickiego byli mu winni niemal 80 tys. zł. O skali tego długu może świadczyć fakt, że była to wartość przekraczająca czterokrotnie wielkość przy-

${ }^{175}$ LBN, f. 93, sygn. 1, Metryka, k. 135v.

176 Tamże.

177 BLAN, f. 40, sygn. 1136, kanon 2 z 1643 r.

178 Tamże, kanon 3 z 1648 r.

179 Tamże, Memorialia, pkt 3 z 1648 r.

180 Tamże, kanon 21 z 1650 r. 
chodów rocznych ze sprzedaży żyta i towarów leśnych eksportowanych $\mathrm{z}$ dóbr Bogusława Radziwiłła ${ }^{181}$.

A nie była to przecież jedyna większa pożyczka udzielona możnym współwyznawcom. Użyczanie środków zgromadzonych w latach sprawnego zarządzania finansami Jednoty najmożniejszym jej protektorom, takim jak Radziwiłłowie czy Abramowiczowie, może być traktowane jako przejaw mądrej, długofalowej strategii inwestycyjnej wspólnoty (inwestycji owocnej ekonomicznie i politycznie). Z drugiej jednak strony, zanim nastapiła stabilizacja ekonomiczna dzięki zapisom Ludwiki Karoliny w latach 80. XVII w. Jednota musiała zmagać się z koniecznością radzenia sobie w szczególnie trudnych momentach nie tylko bez „sum kapitalnych", ale i regularnie wypłacanych od nich odsetek. Zatem w latach 40. i 50. pożyczanie pieniędzy Radziwiłłom, jako filarom kalwinizmu w Wielkim Księstwie Litewskim, było, naszym zdaniem, przysługa, której Jednota nie mogła odmówić, ale z punktu widzenia jej finansów więcej przynosiła kłopotów niż realnych korzyści.

\section{Legaty}

Legaty (łącznie z fundacjami zborów) można uznać za główne źródło dochodów Jednoty Litewskiej. Zestawiając sumy darowizn, można odnieść wrażenie, że znacząco wspomogłyby one materialne funkcjonowanie Kościoła (zob. wykres 4).

W latach 1611-1655 zadeklarowano łącznie legaty pieniężne na sumę 220029 zł. Jednak problem polegał na tym, że przeważająca część legowanych sum oraz dóbr ruchomych i nieruchomych była albo dopiero „obiecana” (przyznanie zapisów prawnych miało dopiero nastapić), albo - w przypadku darowizn legowanych testamentem - należało ją wyegzekwować od pozostałych przy życiu współmałżonków lub potomków. Wpłacono bowiem od razu maksymalnie 70169 zł, czyli około $32 \%$ deklarowanych sum (odpowiednio deklarowano przeciętnie wsparcie rzędu około 4900 zł rocznie, a wpłacano od razu 1550 zł rocznie). Warto przy tym dodać, iż jest to optymistyczna interpretacja zapisów o zrealizowanych od razu legatach, bo można przyjąć też ich wartość minimalna - 55236 zł.

Rozbieżności między deklaracjami i zapisami a realnie przekazywanymi sumami wynikały z różnych przyczyn, np. konieczności zgromadzenia

181 A. Mączak, Pieniadz i społeczeństwo $w$ Rzeczypospolitej XVI-XVII w., RDSG, t. 37,1976 , s. 71 . 
Wykres 4. Wartość zapisów wszystkich i wypłaconych od razu w latach 1611-1655

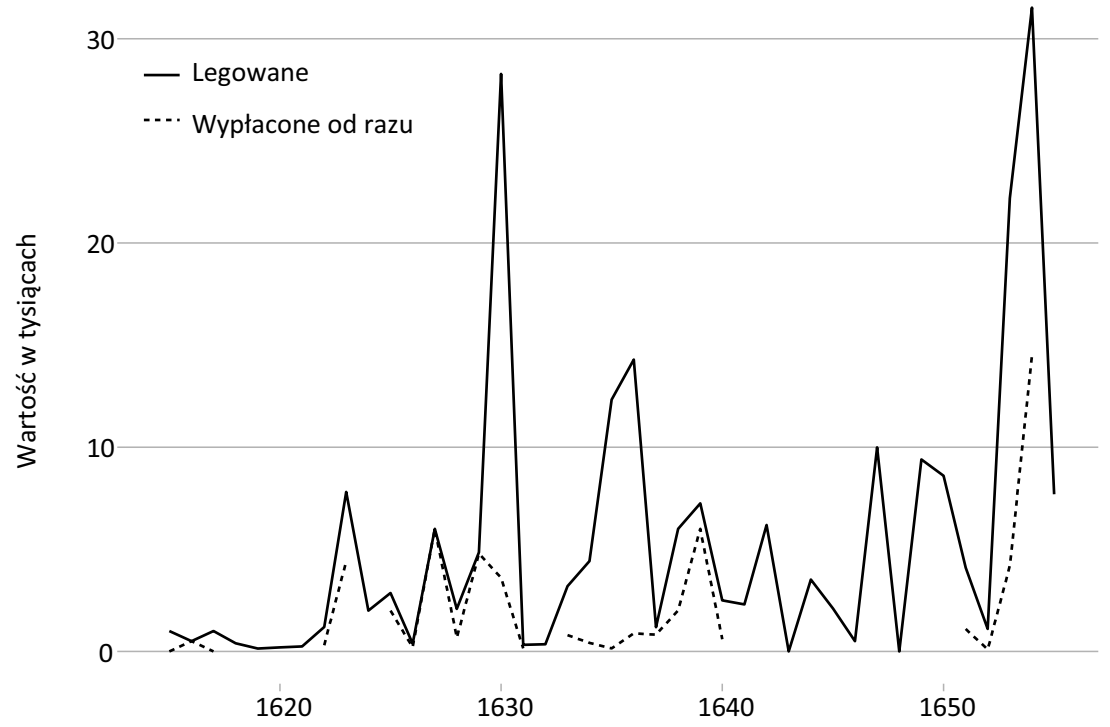

Źródło: oprac. własne na podstawie: BLAN, f. 40, sygn. 1136; Akta synodów prowincjalnych Jednoty Litewskiej 1611-1625, Wilno 1915; Akta synodów prowincjonalnych Jednoty Litewskiej 1626-1637, wstęp i oprac. M. Liedke, P. Guzowski, Warszawa 2011.

zapowiedzianych środków (deklarowano oddanie ich „na przyszłym synodzie”, „Na Boże Narodzenie”, „na św. Marcina” itp.). Żyjący darczyńcy obiecujaccy konkretne sumy, ruchomości czy nieruchomości miewali bieżące, osobiste kłopoty finansowe, odsuwali więc w czasie realizację obietnic, a synod im o tym przypominał. Czasami darowywano nieruchomości z prawem dożywocia, jak chciała np. Marusza z Frąckiewiczów Talwoszowa, kasztelanowa żmudzka, kiedy w 1630 r. zapisywała fundusz zboru w Szylanach ${ }^{182}$, a zatem czerpanie korzyści z takich dóbr przesuwało się w czasie. Bywało też, że spadkobiercy legującego uznawali, że nie chca rozstawać się z określonymi dobrami czy sumami i blokowali oddanie zapisów. Na przykład o legowany w 1619 r. przez pana Bernatowicza folwark w roku następnym toczył się proces ${ }^{183}$. Kilka lat (jeszcze w 1624 r.!) decydowano o pozwaniu wdowy po Jaroszu Jewłaszewskim, pisarzu ziemskim nowogródzkim ${ }^{184}$, który testamentem (w 1620 r.) dokonał fundacji zboru w Dobromyślu ${ }^{185}$. Podobnie kilka lat trwała egzekucja

${ }^{182}$ Akta synodów prowincjonalnych... 1626-1637, s. 75.

183 Akta synodów prowincjalnych... 1611-1625, s. 51, 57.

184 H. Wisner, Przedsejmowy sejmik nowogrodzki w latach 1607-1648, PH, t. 69, 1978, z. 4, s. 679 .

${ }^{185}$ Akta synodów prowincjalnych... 1611-1625, s. 58, 88. 
całości fundacji zboru w Dziewałtowie, dokonanej przez Jerzego Samsona Podbereskiego (1630), marszałka brasławskiego ${ }^{186}$. Dopiero po ośmiu latach Jednota otrzymała zapis przyznania „prawa”187. O wspomniany zapis szylański kasztelanowej żmudzkiej także toczył się proces. Procesy zaś generowały koszty, więc korzyści wynikające z niektórych zapisów można uznać za problematyczne. A trzeba tu dodać, że takie kłopoty z egzekucją legatów pojawiały się nie tylko w sytuacji, kiedy potomkowie legujaccego byli innego wyznania niż on lub dokonali konwersji (wspomniany wyżej zapis marszałka brasławskiego przez wiele lat realizowała jego żona, Dorota z Zawiszów, gorliwa kalwinistka ${ }^{188}$ ). Czasami zapisywano też sumy, które ofiarodawcom były dłużne inne osoby, więc, siłą rzeczy, odzyskiwanie takich legatów nie było łatwe, zwłaszcza jeśli trzeba było negocjować ze znaczniejszymi członkami wspólnoty, jak np. Anną Dorota z Wołłowiczów Abramowiczowa, wojewodziną smoleńską ${ }^{189}$. Część winnej sobie od niej sumy zapisał na zbór ksiądz Kałuski w 1615 r. ${ }^{190}$

\section{Podsumowanie}

W ciagu pierwszej połowy XVII w. zmieniały się warunki polityczno-społeczno-demograficzne, a tym samym finansowe funkcjonowania Jednoty Litewskiej. Wraz z konwersjami potomków rodzin kalwińskich lub wymieraniem niektórych z nich kurczył się stan posiadania wspólnoty ewangelicko-reformowanej, a sprawy finansowe zajmowały coraz więcej miejsca podczas obrad synodów prowincjonalnych. Ewangelicko-reformowana wspólnota wyznaniowa przeżywała trudności ekonomiczne wynikające m.in. z kłopotów z odzyskiwaniem pożyczek, procesami rewindykacyjnymi, niesolidnością niektórych aktorów i szafarzy wspólnoty czy z egzekucją legatów. Trudna sytuacja objawiała się niedofinansowaniem duchownych, którym wypłacano mniejsze

${ }^{186}$ Akta synodów prowincjonalnych... 1626-1637, s. 71. Całość fundacji opiewała na 10 tys. zł i wieś Kromuż. Ponadto w swym testamencie marszałek brasławski zawarł także zapisy na zbór i szpital w Wilnie, szkołę i szpital przy zborze w Dziewałtowie oraz utrzymywanie wdów po ministrach; H. Lulewicz, Podbereski Jerzy, w: PSB, t. 27, Wrocław 1982, s. 67 n.

187 BLAN, f. 40, sygn. 1136, kanon 19 z 1638 r.

${ }_{188}$ H. Lulewicz, Podbereski Jerzy..., s. 67 n.

189 Była żoną Jana Abramowicza, wojewody smoleńskiego (1596-1602), związanego z Radziwiłłami; U. Augustyniak, Testamenty..., s. 46.

190 Akta synodów prowincjalnych... 1611-1625, s. 29. 
wynagrodzenie $^{191}$ (o czym wspominają też tzw. memorialia umieszczane na końcu protokołów synodowych z końca lat 40. XVII w.), ograniczeniem opieki społecznej (np. wstrzymaniem przekazywania środków na wdowy) lub niezrealizowaniem tak ważnych teologicznie pomysłów jak seminarium w Zabłudowie. Ta ostatnia kwestia, jak również prześledzenie historii odzyskiwania legatów znajdą szczegółowe omówienie $\mathrm{w}$ innym miejscu.

W oczywisty sposób potrzebne sa dalsze badania na temat kondycji materialnej duchownych oraz sytuacji finansowej poszczególnych zborów, dystryktów i całej Jednoty, zwłaszcza w drugiej połowie XVII w. Autorzy mają nadzieję, że będa one kontynuowane także z wykorzystaniem szerszej podstawy źródłowej: dokumentacji poszczególnych zborów, zachowanych akt synodów dystryktowych, korespondencji duchownych z patronami i dokumentów fundacyjnych.

\section{Bibliografia}

\section{Źródła rękopiśmienne}

Biblioteka im. E. i E. Wróblewskich Litewskiej Akademii Nauk w Wilnie, f. 40, sygn. 1136, Akta synodów prowincjonalnych jednoty Litewskiej 1638-1675, ks. 2.

Archiwum Główne Akt Dawnych w Warszawie, Archiwum Radziwiłłów, dział VIII, sygn. 713, Odpisy akt synodów prowincjonalnych Jednoty Litewskiej z lat 1611-1686.

Litewska Biblioteka Narodowa im. M. Mażwida w Wilnie, f. 93, sygn. 1, Metryka albo spisanie spraw wieczystych, przywilejów, listów, zapisów i wypisów z różnych ksiąg trybunalskich, ziemskich i grodzkich z rożnych woiewództw y powiatów w W. X. L. będących na zbór wileński y na insze Kościoły w W.X.L.; f. 93, sygn. 1668.

\section{Źródła drukowane}

Akta synodów prowincjalnych Jednoty Litewskiej 1611-1625, Wilno 1915 (Monumenta Reformationis Polonicae et Lithuanicae, IV, 2).

Akta synodów prowincjonalnych Jednoty Litewskiej 1626-1637, wstęp i oprac. M. Liedke, P. Guzowski, Warszawa 2011.

${ }^{191}$ U. Augustyniak, Duchowni klienci..., s. 162. 


\section{Opracowania}

Augustyniak U., Duchowni klienci Krzysztofa II Radziwiłta. Kondycja i funkcje duchowieństwa ewangelicko-reformowanego $w$ dobrach radziwittowskich $w$ pierwszej połowie XVII wieku, w: Radziwitłowie XVI-XVIII w. W kregu polityki i kultury, Warszawa-Łódź 1989 (Miscelanea Historico-Archivistica, 3), s. 159-173.

Augustyniak U., „Druga reformacja” $w$ Wielkim Księstwie Litewskim w pierwszej połowie XVII wieku. W poszukiwaniu tożsamości wyznaniowej, w: Sztuka i dialog wyznań $w$ XVI i XVII wieku. Materiaty Sesji Historyków Sztuki, Wrocław, listopad 1999, red. J. Harasimowicz, Wrocław 2000, s. 223-233. Augustyniak U., Jeszcze raz w sprawie tumultu wileńskiego 1639 i jego następstwach, „Odrodzenie i Reformacja w Polsce” 50, 2006, s. 169-189.

Augustyniak U., Testamenty ewangelików reformowanych $w$ Wielkim Księstwie Litewskim w XVI-XVIII wieku, wyd. 2 popr. i rozsz., Warszawa 2014.

Bagińska E., Dziatalność religijna Radziwittów birżańskich w dobrach podlaskich w XVII wieku, „Studia Podlaskie” 12, 2002, s. 205-228.

Błaszczyk G., Herbarz szlachty żmudzkiej, t. 3, Warszawa 2015.

Dzieje rodziny Ciechanowieckich herbu Dabrowa (XIV-XXI wiek), red. A. Rachuba, Warszawa 2013.

Frick D., Libellius chamorum. Protestancka elita mieszczańska a szlachta $w$ Wilnie XVII wieku, w: Litwa w epoce Wazów. Prace ofiarowane Henrykowi Wisnerowi $w$ siedemdziesiata rocznice urodzin, red. W. Kriegseisen, A. Rachuba, Warszawa 2006, s. 239-255.

Gizbert-Studnicki W., Suplement. Aneks nr. 3, w: H. Merczyng, Wilno ewangelickie, Wilno 1925.

Kempa T., Konflikty wyznaniowe $w$ Wilnie od poczatku reformacji do końca XVII wieku, Torun 2016.

Kosman M., Litewska jednota ewangelicko-reformowana od połowy XVII $w$. do 1939 r., Opole 1986.

Kot S., Geneza i tto historyczne Biblii Litewskiej Chylińskiego, w: Biblia Litewska Chylińskiego. Nowy Testament, t. 2: Tekst, Poznan 1958.

Kraszewski J.I., Wilno od poczattów jego do roku 1750, t. 1, Wilno 1840.

Lulewicz H., Podbereski Jerzy, w: PSB, t. 27, Wrocław 1982.

Lulewicz H., Puzyna Hieronim, w: PSB, t. 29, Wrocław 1986.

Maroszek J., Dzieje zboru kalwińskiego w Zabłudowie w latach 1608-1868, „Rocznik Zabłudowski” 3, 2009, s. 5-55.

Mączak A., Pieniqdz $i$ spoteczeństwo $w$ Rzeczypospolitej XVI-XVII w., RDSG, t. 37, 1976, s. 63-85.

Paknys M., Vilniaus miestas ir miestieciai $1636 \mathrm{~m}$. Namai, gyventojai, sveciai, Vilnius 2006.

Piszcz E., Colloquium Charitativum w Toruniu A.D. 1645. Geneza i przebieg, Toruń 1995.

Sierba M., Kalwiński zbór orlański w XVII wieku, „Białoruskie Zeszyty Historyczne" 44,2015 , s. $45-61$. 
Testamenty $w$ ksieggach miejskich wileńskich z XVI i XVII w. Katalog, oprac. K. Frejlich, Warszawa 2017.

Urzędnicy Wielkiego Księstwa Litewskiego. Spisy, t. 1: Województwo wileńskie, XIV-XVIII wiek, oprac. H. Lulewicz, A. Rachuba, P.P. Romaniuk, współpr. U. Jemialianczuk, A. Macuk, Warszawa 2004.

Urzędnicy Wielkiego Księstwa Litewskiego. Spisy, t. 3: Księstwo żmudzkie, XIV-XVIII wiek, oprac. H. Lulewicz, A. Rachuba, P.P. Romaniuk, A. Haratym, Warszawa 2015.

Wisner H., Przedsejmowy sejmik nowogrodzki w latach 1607-1648, PH, t. 69, 1978, z. 4, s. 677-689.

Wisner H., Likwidacja zboru ewangelickiego w Wilnie (1639-1646). Z dziejów walki z inaczej wierzacymi, „Odrodzenie i Reformacja w Polsce” 37, 1993, s. $89-102$.

Zwolski B., Sprawa Zboru Ewangelicko-Reformowanego $w$ Wilnie w latach 1639-41, Wilno 1936.

Żabiński Z., Systemy pieniężne na ziemiach polskich, Wrocław 1981.

Marzena Liedke

Piotr Guzowski

Financial problems of the Lithuanian Evangelic Unity in the first half of the seventeenth century in the light of records of provincial synods

(Summary)

Opinions about the financial condition of the Lithuanian Evangelical Reformed Church in the first half of the seventeenth century that could be found in the literature on the subject indicate that the financial situation of the Lithuanian Unity was quite satisfactory. But an analysis of the records of the Unity's provincial synods reveals that the Church had to cope with many economic troubles. Its main source of income were private foundations of the churches, monetary and material bequests (landed estates, real properties in town and cities, objects of silver and gold, liturgical vessels, etc.), and various collections of funds among the faithful. The management of legal and financial matters was vested in the office of general actor (legal representative) of the Lithuania's Unity. Financial matters of individual parishes were managed by stewards, and the economic situation of parishes and churches was in the charge of special commissions, appointed when needed. The economic situation of the Lithuanian Unity was influenced by - apart from the intensified Counter-Reformation action of the Roman Catholic Church, conversions or deaths of the most wealthy faithful, noticed in the literature - unreliability of the Unity's main financial officers, actors and stewards, or troubles with the management of loans (even - or especially - made to the most affluent members of the Unity - i.e. the Radziwills), and problems with getting back and receiving donations made to the Unity. Thus, it is difficult to 
maintain unreasonably optimistic opinions about the economic situation of the Evangelical Reformed Church in the Grand Duchy of Lithuania, for - despite the protection of the Radziwills - the material assets of the Unity declined. The Church had to pay for trials and, after 1640, for the transfer of its central church building outside the city walls of Vilnius. Its difficult financial situation was reflected in underfinancing of its priests, who were paid smaller salaries, in smaller social assistance or in abortion of such important for the Church plans as the opening of a seminary at Zabłudów.

Marzena Liedke - pracownik Instytutu Historii i Nauk Politycznych Uniwersytetu w Białymstoku oraz Centrum Badań Struktur Demograficznych i Gospodarczych Przednowoczesnej Europy Środkowo-Wschodniej Uniwersytetu w Białymstoku. Jej zainteresowania badawcze koncentrują się wokół problematyki religijnej, kulturalnej i demograficznej Wielkiego Księstwa Litewskiego w dobie wczesnonowożytnej, szczególnie przemian konfesyjnych szlachty i magnaterii oraz demografii rodziny magnackiej.

Marzena Liedke - employed at the Institute of History and Political Sciences, University of Bialystok, and the Centre for Research on Demographic and Economic Structures of Premodern East-Central Europe, University of Bialystok. Her research interests focuses on problems of religion, culture and demography of the Grand Duchy of Lithuania in the early modern period, especially of confessional transformation of the nobility and magnates, and the demography of a magnate family.

E-mail: mlie@wp.pl.

Piotr Guzowski - pracownik Instytutu Historii i Nauk Politycznych Uniwersytetu w Białymstoku oraz Centrum Badań Struktur Demograficznych i Gospodarczych Przednowoczesnej Europy Środkowo-Wschodniej Uniwersytetu w Białymstoku, a także Instytutu Historii im. Tadeusza Manteuffla Polskiej Akademii Nauk. Zajmuje się historią gospodarczą i demografią historyczną okresu preindustrialnego.

Piotr Guzowski - employed at the Institute of History and Political Sciences, University of Bialystok, and the Centre for Research on Demographic and Economic Structures of Premodern East-Central Europe, University of Bialystok, and the Tadeusz Manteuffel Institute of History, Polish Academy of Sciences. He specialises in economic and demographic history of the preindustrial period. E-mail: guzowski@uwb.edu.pl. 